\title{
Thermal Analysis Technologies for Biomass Feedstocks: A State-of-the-Art Review
}

\author{
Jun Sheng Teh ${ }^{1}$, Yew Heng Teoh ${ }^{1, * \mathbb{D}}$, Heoy Geok How ${ }^{2}$ and Farooq Sher ${ }^{3, * \mathbb{D}}$ \\ 1 School of Mechanical Engineering, Universiti Sains Malaysia, Engineering Campus, \\ Nibong Tebal 14300, Penang, Malaysia; sheng97@student.usm.my \\ 2 Department of Engineering, School of Engineering, Computing and Built Environment, \\ UOW Malaysia KDU Penang University College, 32 Jalan Anson, Georgetown 10400, Penang, Malaysia; \\ heoygeok.how@kdupg.edu.my \\ 3 Department of Engineering, School of Science and Technology, Nottingham Trent University, \\ Nottingham NG11 8NS, UK \\ * Correspondence: yewhengteoh@usm.my or yewhengteoh@gmail.com (Y.H.T.); \\ Farooq.Sher@ntu.ac.uk or Farooq.Sher@coventry.ac.uk (F.S.)
}

Citation: Teh, J.S.; Teoh, Y.H.;

How, H.G.; Sher, F. Thermal Analysis Technologies for Biomass Feedstocks: A State-of-the-Art Review. Processes 2021, 9, 1610. https://doi.org/ $10.3390 /$ pr9091610

Academic Editor: Jin Bai

Received: 15 May 2021

Accepted: 31 August 2021

Published: 8 September 2021

Publisher's Note: MDPI stays neutral with regard to jurisdictional claims in published maps and institutional affiliations.

Copyright: (c) 2021 by the authors. Licensee MDPI, Basel, Switzerland. This article is an open access article distributed under the terms and conditions of the Creative Commons Attribution (CC BY) license (https:/ / creativecommons.org/licenses/by/ $4.0 /)$.

\begin{abstract}
An effective analytical technique for biomass characterisation is inevitable for biomass utilisation in energy production. To improve biomass processing, various thermal conversion methods such as torrefaction, pyrolysis, combustion, hydrothermal liquefaction, and gasification have been widely used to improve biomass processing. Thermogravimetric analysers (TG) and gas chromatography (GC) are among the most fundamental analytical techniques utilised in biomass thermal analysis. Thus, GC and TG, in combination with MS, FTIR, or two-dimensional analysis, were used to examine the key parameters of biomass feedstock and increase the productivity of energy crops. We can also determine the optimal ratio for combining two separate biomass or coals during co-pyrolysis and co-gasification to achieve the best synergetic relationship. This review discusses thermochemical conversion processes such as torrefaction, combustion, hydrothermal liquefaction, pyrolysis, and gasification. Then, the thermochemical conversion of biomass using TG and GC is discussed in detail. The usual emphasis on the various applications of biomass or bacteria is also discussed in the comparison of the TG and GC. Finally, this study investigates the application of technologies for analysing the composition and developed gas from the thermochemical processing of biomass feedstocks.
\end{abstract}

Keywords: renewable energy; thermochemical conversion; thermal analysis; thermogravimetric analysers; gas chromatograph; biomass and sustainability

\section{Introduction}

Global energy demand has increased significantly over the last few decades due to the rising global population and economic prosperity. As a result, fossil fuel stocks are depleting, air pollution is on the rise, and greenhouse gas (GHG) emissions are increasing [1]. Many attempts have been made with an emphasis on overcoming these issues through the development of clean energy and alternative fuels. Even though renewable energy applications have grown rapidly in recent years, they remain limited due to high costs, low technology efficiency, and a limited supply of resources [2]. Biomass energy or bioenergy is one of the crucial challenges in meeting the requirements of substituted fossil fuels for reducing GHG emissions among the green energy and alternative fuels used in power generation [3]. The use of biomass will lower the country's greenhouse gas emissions. When fossil fuels are burned, they release massive amounts of carbon dioxide into the atmosphere, which is carbon that would otherwise remain trapped underground. Heat and catalysts are used in the thermochemical processing of biomass to convert plant biomass into fuels, chemicals, or electric power. It has been used to treat crude oil in order to extract fossil fuels and various chemical products [4]. 
Biomass is one of the most adaptable, diverse, green, and renewable energy options available. Since the dawn of civilisation, it has been a primary source of energy for heating and cooking applications, especially in rural areas of developing countries [2]. Furthermore, in the present scenario, it contributes to a significant amount of overall electricity across the globe. Biomass can be harvested from several sources for long-term syngas processing, including timber wood and residuals, agricultural residues, aquaculture, biological byproducts, drainage organic parts, and urban wastes [5]. The use of lignocellulosic biomass for energy production allows for the use of small-scale cogeneration units, lowering feedstock transportation costs, and making the energy system more robust to failures. To ensure continuous energy production and to handle a diverse biomass mix, the energy production equipment should be able to employ a variety of fuel types [6].

Biological and thermochemical processes are the most common methods for converting biomass into energy. Biological methods are widely used to produce hydrogen in biomass energy conversions. Figure 1 shows five distinct types of thermochemical processes. The thermochemical conversion of biomass is a viable option for overcoming the challenges associated with using biomass as a biofuel. The primary goal of thermochemical conversion processes is to reduce undesirable by-products by optimising process parameters. During the thermochemical conversion, heat and chemical processes are used to produce biofuel with high quality and densified energy content. Torrefaction, pyrolysis, combustion, liquefaction, and gasification are some of the thermochemical conversion processes that are used to transform lignocellulosic and non-lignocellulosic biomass into biofuels [7]. The research community and industry have shown an increased interest in the thermochemical conversion of biomass to transportation fuels. This green energy option has the potential to replace petroleum-derived fuels, benefiting many countries. Thermochemical biofuels are often produced locally and can help a country's trade balance and national security [8].

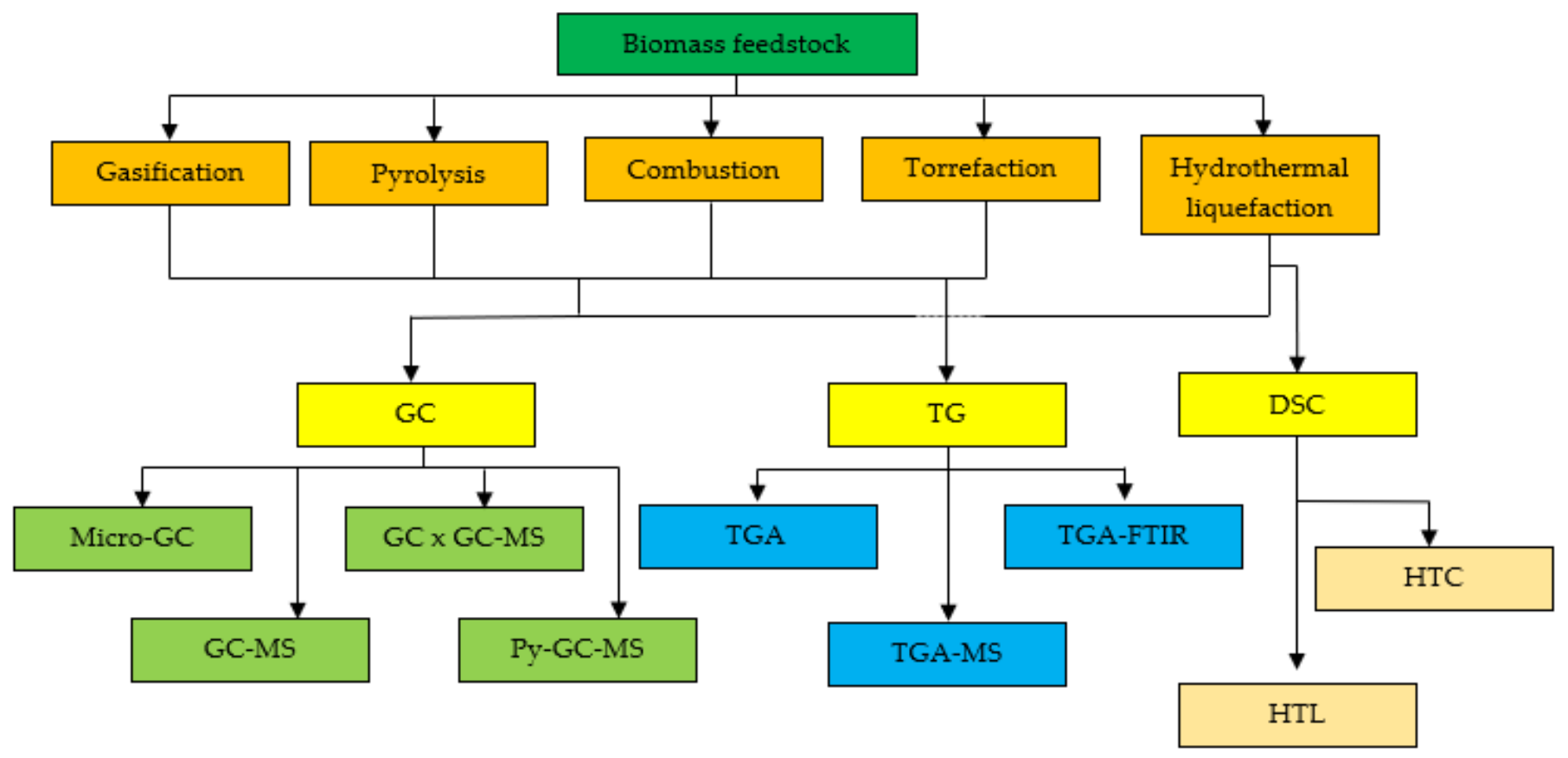

Figure 1. Schematic of analytic techniques for thermochemical conversion process.

This review focuses on recent advances in thermochemical conversion technology used to produce electricity, fuels of electricity, fuels, and chemicals from biomass. The combustion mechanism uses oxidation combustion reactions to produce heat from biomass. This review also focuses on thermochemical analytical methods because this is a proven science that has been used on a commercial scale. To gain a deeper understanding of 
the complexities and challenges of biomass conversion, biomass technology must first be defined [9]. Thermogravimetric analysis (TGA) is a thermal analytic technology that uses a thermogravimetric analyser (TG) to examine the mass shift of a sample with an increase in temperature and time [10]. TG has been an alternative way of studying the proximate analysis of biomass using reduced energy input to save money and time using ASTM requirements [11]. The functional groups and chemical structures of biomass and its products from thermochemical conversion can be identified primarily by observing changes in structure, heteroatomic functions, and mineral composition using Fourier transform infrared spectroscopy (FTIR) [12].

Along with other chromatographic methods, GC is critical in forensic research for separating substances of analytical significance. The idea behind chromatography is that molecules in a mixture are attracted to a surface or a solid, with the fluid stationary phase breaking apart and spinning with the aid of a mobile phase. Molecular characteristics such as adsorption, partition, and affinity, as well as variations in their molecular weights, are efficient in this separation process. Any components of the mixture will spend more time in the stationary phase and enter the chromatography system slowly, whereas others will enter the mobile phase rapidly and leave the system faster [13]. Chromatography is a technique for distinguishing molecules based on their distribution in a mobile and stationary phase. A liquid or gas may be used as the mobile phase. The stationary phase may be either a solid or a liquid, whereas a solid can hold a liquid stationary phase in place. The support or matrix is the solid that holds the liquid stationary phase in place [14] Differential scanning calorimetry (DSC) is a thermo analytical technique that analyses a polymer's thermal properties using a differential scanning calorimeter. This approach calculates the difference between the amount of heat required to raise the temperature of a sample and a reference as a function of temperature. Furthermore, this review is aimed to present thermal technologies and methods for analysing the composition of the mixture of products formed during the high-temperature decomposition of biomass feedstock. This review focuses on the products and composition of the biomass feedstock. This review also contains individual definitions and principles of TGA and GCMS, as well as their effect on the biomass thermochemical conversion process.

\section{Thermochemical Conversion Process}

The flexibility of feedstock used, product distribution (solid, liquid, and gas), and product upgrading are currently gaining researchers' interest in thermochemical technology [15]. Generally, torrefaction, combustion, pyrolysis, gasification, and hydrothermal liquefaction are the five types of thermochemical conversion technologies for biomass [7]. Experiments on the thermochemical conversion of various biomass feedstocks at various operating conditions such as temperature, residence time, and pressure are being conducted in the lab and also on a pilot scale [16].

\subsection{Gasification}

Gasification is a chemical reaction that transforms carbonate elements into raw chemical substrates or gaseous fuels. The resulting gas mixture is known as synthesis gas, or syngas [17]. Using gasification process, a carbon-based feedstock is dissociated at high temperatures from 700 to $1500{ }^{\circ} \mathrm{C}$ under sub-stoichiometric conditions. The oxidising medium can be air, steam, pure oxygen, or a combination of these [18]. In gasification, biomass is heated to high temperatures exceeding $700{ }^{\circ} \mathrm{C}$ to produce syngas, which can be converted to liquid transportation fuels [19]. This method is based on a decade of experience with coal gasification. $\mathrm{H}_{2}$ and $\mathrm{CO}$ contribute roughly $50 \%$ of the energy in commodity gas, whereas $\mathrm{CH}_{4}$ and aromatic hydrocarbons contribute the remaining energy [20]. In the biomass method, the gasification of fossil fuels is common for the production of syngas $\left(\mathrm{CO}, \mathrm{H}_{2}, \mathrm{~N}_{2}\right.$, and $\left.\mathrm{CO}_{2}\right)$, and a few hydrocarbon elements or compounds make up the majority of the syngas $\left(\mathrm{CH}_{4}, \mathrm{C}_{2} \mathrm{H}_{4}\right.$ and $\mathrm{C}_{2} \mathrm{H}_{6}$ etc.) [21]. The gasification process produces 
heat when operates in an oxygen-deficient environment. Hence, a medium reaction, such as air, oxygen, subcritical steam, or certain gaseous mixtures, is required [22].

Co-gasification of coal and biomass supplies can be useful for a variety of reasons, including the fact that biomass has a high oxygen content, requiring less additional oxygen for the gasification system [23]. Compared to coal, biomass supplies have lower levels of ash, sulphur, and nitrogen. In the presence of an oxidising agent, co-gasification typically occurs at temperatures above $800{ }^{\circ} \mathrm{C}$. The temperature needed for gasification is typically achieved by directly or indirectly heating the gasifier using strand and oxidising agents. The massive cellulosic and lignin molecules in the biomass degrade lighter molecules, which are then converted into gases such as $\mathrm{CO}, \mathrm{H}_{2}, \mathrm{CH}_{4}$ and lighter hydrocarbons, as well as ash, char, tar, and small impurities [24]. The gasification process is highly dependent on operational parameters. The process involves various mechanisms such as biomass drying, pyrolysis, combustion, and reduction, all of which must be carried out under optimal conditions to achieve the desired end-product efficiency.

The gasification process involves the production of tar for syngas generation. A viable option for removing tar from gas products is catalytic steam reforming of tar into syngas [25]. Supported Ni-based catalysts are effective for catalytic reforming of biomass tar, which has the potential to produce syngas and be further synthesised by the FischerTropsch reaction [26]. In a gasifier, a reaction kinetics model of hydrogen generation by biomass steam gasification with calcium oxide as sorbent was created. The biomass gasification process is influenced by the performance of each reaction represented in the model. The waster-gas shift reaction and methane steam are the two major processes that led to $\mathrm{H}_{2}$ generation. The findings revealed that the molar fraction of $\mathrm{H}_{2} \mathrm{O}$ increased from 0.065 to 0.83 , whereas the molar fraction of $\mathrm{CO}_{2}$ decreased from 0.31 to 0.09 [27]. The char represented by $x$ terms from gasification conversion rate is stated in Equation (1).

$$
\mathbf{x}=\frac{w_{0}-w_{t}}{w_{0}-w_{f}} \times 100 \%
$$

where $w_{0}$ is the sample's initial mass, $w_{t}$ is the sample's mass over time, and $w_{f}$ is the sample's final mass. A well-established data analysis approach was used to investigate the reaction mechanism involved in a heat conversion process. The general response rate $(\mathrm{dx} / \mathrm{dt})$ is considered to be a function of the conversion $(\mathrm{x})$ and a rate constant $(\mathrm{k})$ and it can be written as Equation (2).

$$
\frac{\mathrm{dx}}{\mathrm{dt}}=\mathrm{kf}(\mathrm{x})
$$

The plausible model of the reaction is denoted by $f(x)$, The Arrhenius equation could be used to define the temperature-dependent gasification reaction rate constant $(\mathrm{k})$ as represented in Equation (3).

$$
\mathrm{k}=\mathrm{A} \exp \left(-\frac{\mathrm{E}}{\mathrm{RT}}\right)
$$

where $\mathrm{A}$ is the pre-exponential factor $\left(\mathrm{min}^{-1}\right), \mathrm{E}$ is the activation energy $(\mathrm{kJ} / \mathrm{mol}), \mathrm{T}$ is the absolute temperature $(\mathrm{K})$, and $\mathrm{R}$ is the gas constant $(8.314 \mathrm{~J} /(\mathrm{mol} \cdot \mathrm{K})$ [28]. To recover additional energy, most commercial gasification plants that handle municipal solid wastederived feedstock use a secondary combustion chamber to burn the syngas and recover energy from a steam circuit. Another important by-product of gasification is solid leftovers of non-combustible materials containing a modest quantity of carbon. At various phases of the gasification process, high-temperature plasma gasification methods are also used. This plasma technology can generate tar-free, pure syngas, and the ash may be fused into glassy or vitreous residue [29]. The energetic efficiency $\left(\eta_{\text {ex }}\right)$ is the performance criterion used in the process performance condition. It is defined as the proportion of lucrative energy outputs flowing from the gasifier to the necessary energy input flow [30]:

$$
\eta_{\mathrm{ex}}=\frac{£ x_{\text {gas }}+£ x_{\text {loss }}+£ x_{\text {tar }}+£ x_{\text {char }}}{£ x_{\text {biomass }}+£ x_{\text {steam }}}
$$


where $£ x_{\text {gas }}, £ x_{\text {tar }}, £ x_{\text {char }}, £ x_{\text {biomass }}$, and $£ x_{\text {steam }}$ are the loss energy flow and energy flow of gas, tar, char, biomass, and steam, respectively. Entropy creation, heat and mass transfers, and irreversibility of chemical reactions all result in a loss. The first and second thermodynamic laws must be followed in the gasification process. As a result of the second law, it is obtained by the following expression:

$$
\sum_{R} £ x-\sum_{P} £ x=I
$$

where $£ x$ denotes energy and I denotes irreversibility, and it denotes the internal energy lost as a result of material quality deterioration and energy dissipation [31].

\subsection{Pyrolysis}

Pyrolysis is the thermochemical conversion of biomass by thermal movement into volatiles, steam, and a mixture of liquid compounds in an inert environment [32]. Organic feedstocks will be pyrolysed to yield three products: a liquid, a syngas, and a solid. During pyrolysis, natural polymeric components are broken down into volatile vapours comprising $\mathrm{O}$ - and $\mathrm{H}$ - containing forms, resulting in bio-oil. These gases can be condensed into bio-oil or recycled later in the pyrolysis process to help with energy requirements for upstream feedstock drying and carbonisation. In the resulting biochar, carbonisation accelerates the removal of polar functional groups and the rearranging of ring or linear shaped organic structures into polycondensation aromatic sheets. Carbonisation requires low oxygen levels to occur while limiting $\mathrm{CO}_{2}$ and $\mathrm{NO}_{x}$ production [33].

The thermochemical pyrolysis process works well in the absence of oxygen at temperatures between 350 and $550{ }^{\circ} \mathrm{C}$ [34]. The pyrolysis mechanism can be divided into three groups based on three principles: slow pyrolysis, fast pyrolysis, and flash pyrolysis. Different pyrolysis systems have different operating conditions and outcomes. During slow pyrolysis, the heating rate is less than $1^{\circ} \mathrm{C} / \mathrm{s}$, the pyrolysis temperature ranges between $300{ }^{\circ} \mathrm{C}$ and $700{ }^{\circ} \mathrm{C}$, and the pyrolysis residence time exceeds $450 \mathrm{~s}$. Fast pyrolysis occurs at temperatures between $500{ }^{\circ} \mathrm{C}$ and $1250{ }^{\circ} \mathrm{C}$, with a heating rate is between $10{ }^{\circ} \mathrm{C}$ and $300{ }^{\circ} \mathrm{C} / \mathrm{s}$. Pyrolysis takes 0.5 to $200 \mathrm{~s}$ to complete. Lastly, the flash pyrolysis heating rate exceeds $1000{ }^{\circ} \mathrm{C} / \mathrm{s}$, and the pyrolysis temperature ranges between $800{ }^{\circ} \mathrm{C}$ and $1300{ }^{\circ} \mathrm{C}$. Pyrolysis takes less than $0.5 \mathrm{~s}$ to complete [35].

Long polymeric chains of cellulose, lignin, hemicellulose, pectin, and other polymers make up the majority of biomass. During the pyrolysis process, larger molecules of organic materials begin to disintegrate into smaller molecules, which are discharged from the process stream as gases, condensable vapours, and solid char. Temperature, time, heating rate, and pressure, as well as the types of precursors and reactor design and configuration, all influence the proportion of each end product. In pyrolysis operations, the moisture content of biomass is also important. During the fast pyrolysis process, the moisture level of the feedstock should be around $10 \%$ [31].

Co-pyrolysis and normal pyrolysis have almost identical pathways. The procedure is essentially carried out in a closed reactor environment with a low operating temperature and no oxygen. The co-pyrolysis process has three basic steps that are necessary for oil production: sample preparation, co-pyrolysis, and condensation [36]. During pyrolysis, oxygen-containing compounds (aldehydes, phenols, ketones, and organic acids) are formed, making the bio-oil unstable and acidic. Catalytic pyrolysis can produce a high-quality bio-oil. As opposed to non-noble metal catalysts, a noble metal-supported catalyst can produce bio-oil from low oxygen-containing compounds. The produced bio-oil can be refined for use in petroleum refineries [37]. The pyrolysis reaction kinetics for lake sediment may be characterised using the Arrhenius equation in Equation (4).

$$
\frac{d a}{d t}=\mathrm{k}(\mathrm{T}) \mathrm{f}(\mathrm{a})=\mathrm{A} \exp \left(-\frac{E}{\mathrm{RT}}\right) \mathrm{f}(\mathrm{a})
$$


where $\mathrm{f}(\mathrm{a})$ is the mechanism function equation, $\mathrm{A}$ is the preexponential factor $\left(\mathrm{s}^{-1}\right), E$ is the activation energy $(\mathrm{kJ} / \mathrm{mol})$, and $\mathrm{R}$ is the universal gas constant $(\mathrm{J} / \mathrm{mol} \cdot \mathrm{K})$, $a$ is the reaction conversion degree, $\mathrm{t}$ is the time $(\mathrm{min})$ and $\mathrm{T}$ is the temperature $(\mathrm{K})$. The value $\mathrm{a}$ is obtained by solving the following Equation (5).

$$
\mathbf{a}=\frac{w_{i}-w}{w_{i}-w_{f}}
$$

where $w$ is the mass of the sample at time $t(\mathrm{mg})$, and $w_{i}$ and $w_{f}$ are the sample's initial and final masses (mg), respectively [38]. For energy computation, the energy flux into and out of the pyrolysis system is included in the control volume, as shown in Figure 2. The electrical energy for the reactor and the energy from the biomass are considered energy inputs. The energy outputs are the energy from bio-oil, charcoal, and non-condensable gases (NCG). The system boundary is defined under ambient conditions, as shown in Figure 2. As a result, heat transfer is no longer an energy contributor. Other energy sources and outputs are minor and insignificant [39].

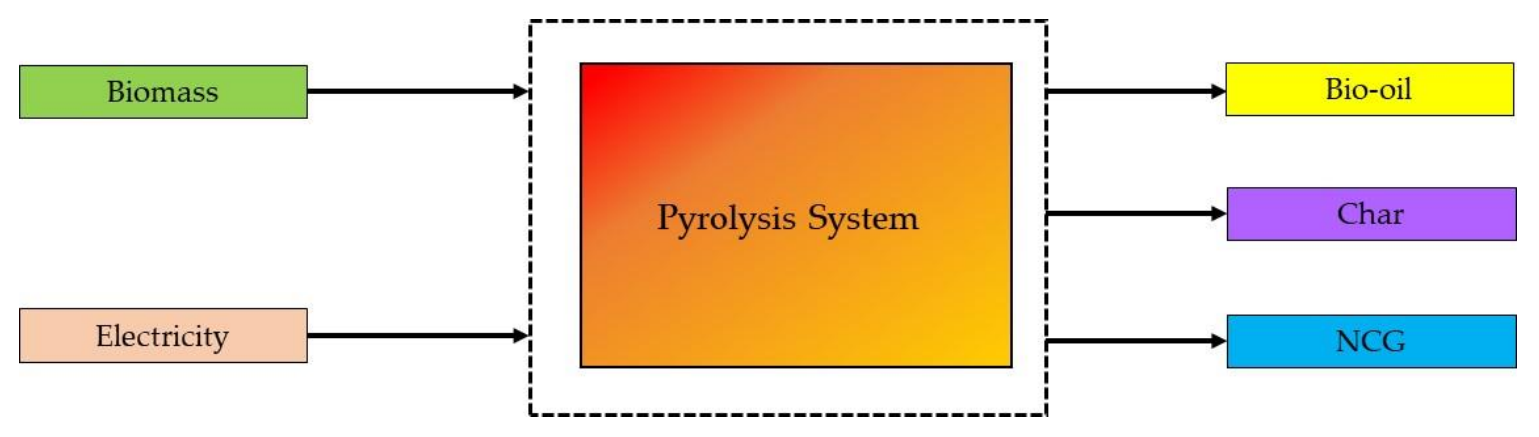

Figure 2. The schematic representation of energy flow process in a pyrolysis system [40].

The solid residue left over from the pyrolysis process may contain significant levels of heavy metals, necessitating the use of a stabilisation technique. The vitrification process has been investigated as a disposal solution that is close to the zero-landfilling scenario because it produces an invert vitreous matrix that can be used as a raw material in the glass industry or as an additive for cement, mortars, and plasters; additionally, it allows the simultaneous stabilisation of other materials with disposal problems [40].

\subsection{Combustion}

Combustion is a complex process involving mass transfer and fluid discharge as well as combined heat and chemical reactions [37]. The volume ratios of oxygen and nitrogen in binary mixtures of air are $21 \%$ and $79 \%$, respectively. Further constituents may be found in an air mixture, but this is unimportant for combustion and gross analysis in this chemical reaction. The combustion process produces a hot gas with temperatures ranging from 700 to $1000{ }^{\circ} \mathrm{C}$. For biomass combustion, the biomass feedstock must be pre-dyed at around $50 \%$ humidity [41]. As a result, combustion is a cost-effective technology for converting biofuel and producing heat. Biofuel production is not exactly modern technology, because no biofuels are generated until the complete combustion of the raw feedstock. Residual gas occurs in the complete or partial combustion of hydrocarbons in the case of oxygen, which includes a few combustion components and gaseous blends [42].

The ability of fuel molecular structures to reproduce the important radical species that affect endothermic and exothermic properties throughout the reaction history, radical consumption, regeneration, and chain branching descriptions for the relevant combustion behaviours are all important influences on combustion kinetic phenomena. The required behaviours for long hydrocarbons typically change with reaction temperature and pressure, resulting in pressure and temperature regimes governed by widely diverse reaction pathways [43]. At high temperature (>1100 K), fuel oxidative pyrolysis, fragment interac- 
tions, and the reactions of $\mathrm{CO}+\mathrm{OH} \leftrightarrow \mathrm{CO}_{2}+\mathrm{H}$ and $\mathrm{H}+\mathrm{O}_{2} \leftrightarrow \mathrm{O}+\mathrm{OH}$ are important mechanisms that determine the heat release rate and radical histories [44].

For well-maintained lean combustion systems, the assumption of full combustion, in which all of the fuel carbon reacts to carbon dioxide, all the fuel hydrogen responds to $\mathrm{H}_{2} \mathrm{O}$, all of the fuel sulphur reacts to $\mathrm{SO}_{2}$, and all of the fuel nitrogen reacts to $\mathrm{N}_{2}$, is usually reasonable. This assumption is a good initial approximation for the species and energy balances. At high temperatures, other species such as $\mathrm{CO}$ and $\mathrm{NO}$ are present in considerable amounts in combustion products [45]. Food residue (40 to 50\%), paper (30 to $40 \%)$, plastic $(12 \%)$, fibre $(3 \%)$, and other materials were often found in the separated municipal solid waste (MSW) following the mechanical treatment stage of the Korean mechanical biological treatment system. Season, culture, and other factors influence the composition of MSW (e.g., food residue and paper components can range between 70\% and $80 \%$ of the total of MSW) [46].

\subsection{Torrefaction}

Torrefaction, a thermochemical technology, is thought to be an easy and inexpensive way to convert the properties of biomass to be almost identical to those of coal [47]. The Energy Centre of the Netherlands $(\mathrm{ECN})$ was the first to investigate coal and torrefied biomass co-firing for energy generation, resulting in a comprehensive ECN study in 2005 [48]. An increase in torrefaction residence time resulted in a decrease in the hydrogen and oxygen composition of biomass in comparison to carbon, resulting in a decrease in the volatile matter content of biomass [49]. Torrefaction has also been widely identified as a promising thermal pre-treatment method for biochar processing, converting low-quality biomass into a high-energy-density, low-moisture feedstock [50].

Torrefaction is characterised by the partly regulated and isothermal pyrolysis of biomass at temperatures ranging from 200 to $300{ }^{\circ} \mathrm{C}$. It is a method of slowly heating biomass in an inert environment to a maximum temperature of $300{ }^{\circ} \mathrm{C}$. When compared to raw biomass, the treatment produces a solid, uniform product with lower moisture and higher energy content. Unbound water is removed from the biomass during the initial heating of torrefaction. The thermal condensation mechanism extracts the bound water at temperatures above $160^{\circ} \mathrm{C}$. The decomposition of hemicellulose begins when the temperature is increased from 180 to $270{ }^{\circ} \mathrm{C}$. The process becomes fully exothermic at a temperature above $280^{\circ} \mathrm{C}$, resulting in a significant increase in the output of $\mathrm{CO}_{2}$, phenols, acetic acid, and other higher hydrocarbons [51].

Torrefaction is the process of devolatilisation and carbonisation of biomass polymers. All these polymers do not always degrade completely within the restricted temperature range of torrefaction between 200 and $300^{\circ} \mathrm{C}$. Different temperature ranges cause different polymers to deteriorate. Examples of qualitative values as given: hemicellulose (225 to $\left.300{ }^{\circ} \mathrm{C}\right)$, cellulose $\left(305\right.$ to $\left.375^{\circ} \mathrm{C}\right)$, and lignin $\left(250\right.$ to $\left.500{ }^{\circ} \mathrm{C}\right)$ [52]. Solid, liquid, and gaseous products are produced during the torrefaction process. The solid component is mostly char, with some sugar, polymeric structures, and ash thrown in the mix. $\mathrm{CO}, \mathrm{CO}_{2}$, and small amounts of $\mathrm{CH}_{4}$ are among the non-condensable gases. Water from thermal decomposition, lipids such as terpenes and waxes, and organics such as alcohols and furans make up condensed liquid. Carbon water, carbon dioxide, carbon monoxide, acetic acid, methanol, and formic acid are all products of torrefaction. Decarboxylation is the process that produces $\mathrm{CO}_{2}$. Acetic acid is formed when the acetyl pendant group in cellulose decomposes. Carbon monoxide is produced primarily by the reaction of $\mathrm{CO}_{2}$ and steam with the porous char surface of biomass [53].

The kinetic energy of Miscanthus is greater than that of wheat straw, implying that the torrefaction of Miscanthus requires more energy than the torrefaction of wheat straw. Similarly, higher activation energy indicates a smooth reaction, whereas lower activation energy indicates a fast reaction. Torrefied biomass is more reactive than raw biomass [54]. Figure 3 indicates that about $70 \%$ of the original biomass weight and $90 \%$ of the original biomass energy are recovered, while the remainder (30\% biomass weight and $10 \%$ biomass 
energy) is discharged as liquids and gases. As a result, it is viewed as a potential for studying wastes as a torrefaction feedstock [55].

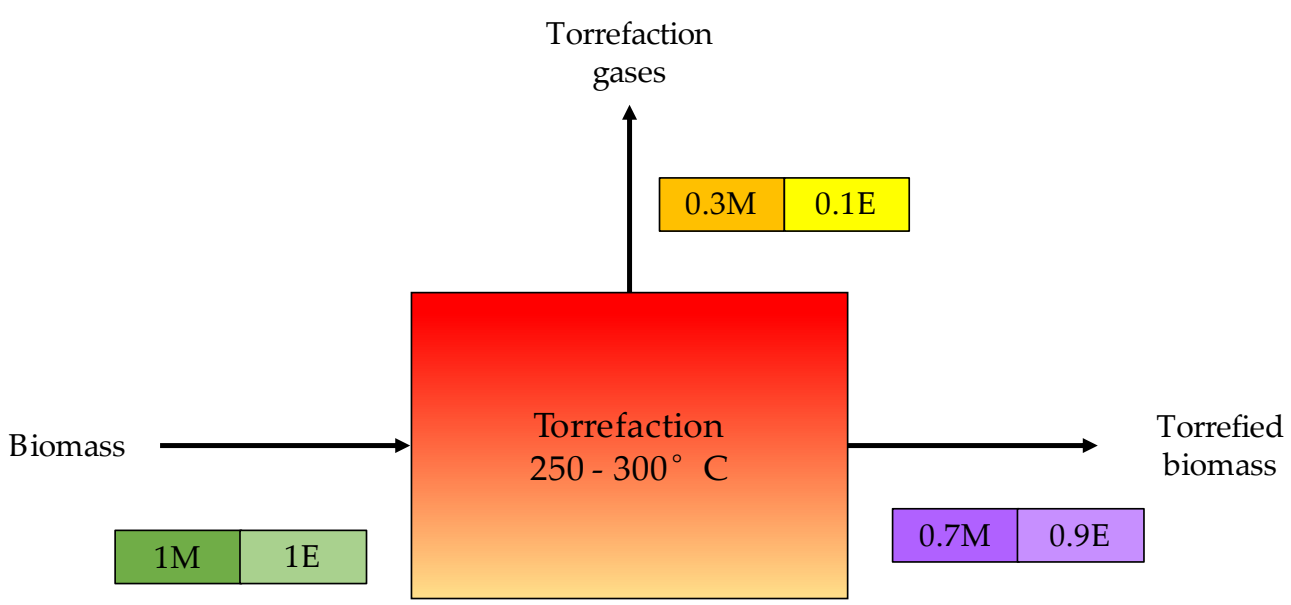

Figure 3. Typical mass and energy balance of the torrefaction process [55].

\subsection{Hydrothermal Liquefaction}

Hydrothermal liquefaction is a thermochemical process that transforms wet biomass into a liquid fuel [56]. Liquid bio crude oil is the main component of this reaction, with solid, liquid, and gaseous by-products. Liquefaction occurs in thermally compressed water at temperatures ranging from 250 to $550^{\circ} \mathrm{C}$ and compressed pressures ranging from 5 to $25 \mathrm{MPa}$. There is no need for a drying phase or digestate method in this reaction [57]. Biocrude, a component of petroleum oil, is the primary commodity. Biocrude has a lot of potential now that has been strengthened. The use of alkaline catalysts reduces the deposition of char while increasing the yield and strength of the oil [58]. Hydration is a chemical reaction in which the principal chemicals in cement create chemical interactions with water molecules, resulting in the formation of hydrates. The next part delves into the hydration process in greater depth. To avoid side reactions that could weaken the concrete or interfere with the hydration process, the water must be pure. Water plays a vital role in the construction of "ideal" concrete, since the water-to-cement ratio is the most important aspect. Too much water will weaken the concrete, while too little will render it unusable.

Concrete must be workable to be solidified and moulded into various shapes. When creating concrete, a careful balance of the cement-to-water ratio is essential, since it must be both strong and workable [59]. Through-solution processes are also common in hydration processes involving acid-base interactions. $\mathrm{Ca}(\mathrm{OH})_{2}$ and glassy $\mathrm{SiO}_{2}$ do not react significantly when mixed as dry powders, but in the presence of liquid water, $\mathrm{Ca}(\mathrm{OH})_{2}$ dissolves significantly, and the resulting solution's alkalinity is sufficient to promote silica hydrolysis; then, the reaction between calcium and silicate ions in alkaline solution is rapid, precipitating calcium silicate hydrate (C-S-H) gel. This emphasises the relevance of reactive species availability; their presence does not always imply that they are available for response. For example, most natural silicas and aluminosilicates are insoluble in water at close to neutral $\mathrm{pH}$ and so unreactive even when dissolved aqueous calcium or magnesium ions are present. However, as alkalinity rises, their solubility rises, resulting in higher aqueous silicate and aluminate concentrations and faster reaction rates. As a result, the solubility properties of the reactants in the aqueous phase have a significant impact on cement hydration reaction rates [60].

Among all of the conversion processes, hydrothermal carbonisation (HTC) is a promising technology. It is a thermochemical method that pre-heats high-moisture biomass with hot compressed water, making it useful for a variety of applications. It is carried out in a closed reactor at 180 to $280^{\circ} \mathrm{C}$ and 2 to $6 \mathrm{MPa}$ for 5 to $240 \mathrm{~min}$ [61]. Hydrothermal carbonisation generates a coal-like substance termed hydro char as its principal product as well as aqueous and gas phases as by-products [62]. The amount of hydro char produced 
depends on the process parameters and feedstock used. Decarboxylation, dehydration, and polymerisation are the major mechanisms involved in this process. Wet biomass makes a good solvent and reaction environment because its ionic product is greatest at temperatures between 200 and $280^{\circ} \mathrm{C}$, in which water may serve as both a base and an acid. Furthermore, the dielectric constant of water decreases at high temperatures, making it behave more as a nonpolar solvent. The benefit of hydrothermal carbonisation is that biomass can be converted to carbonaceous solids without the need for an energy-intensive drying process. The energy-to-weight ratio of hydro char is higher than that of the initial material [63].

\subsection{Comparison of Thermal Technologies}

Table 1 shows the comparison of five typical thermochemical processes. As can be seen, each of the given processes is subjected to a range of temperatures and pressures for the conversion and to obtain the desired results.

Table 1. Comparison of five thermochemical conversion processes.

\begin{tabular}{|c|c|c|c|c|c|c|}
\hline $\begin{array}{l}\text { Thermochemical } \\
\text { Process }\end{array}$ & $\begin{array}{c}\text { Temperature } \\
\left({ }^{\circ} \mathrm{C}\right)\end{array}$ & Pressure (MPa) & Gas Products & Pollutants & Purpose & Advantages \\
\hline Gasification & 500 to 1300 & $\geq 0.1$ & $\begin{array}{l}\mathrm{CO}_{2}, \mathrm{H}_{2}, \mathrm{CO}_{2}, \mathrm{H}_{2} \mathrm{O} \\
\quad \text { and } \mathrm{CH}_{4}\end{array}$ & $\begin{array}{l}\mathrm{H}_{2} \mathrm{~S}, \mathrm{NH}_{3} \text {, tar, } \\
\text { and dust }\end{array}$ & $\begin{array}{l}\text { Converting biomass } \\
\text { to high HV gas }\end{array}$ & $\begin{array}{l}\text { Production of a wide range of } \\
\text { chemical products and the } \\
\text { ability to adapt to changing } \\
\text { market conditions. }\end{array}$ \\
\hline Pyrolysis & 300 to 1000 & 0.1 to 0.5 & $\begin{array}{l}\mathrm{CO}, \mathrm{H}_{2}, \mathrm{CH}_{4} \text {, and } \\
\text { other hydrocarbons }\end{array}$ & $\begin{array}{l}\mathrm{H}_{2} \mathrm{~S}, \mathrm{NH}_{3}, \text { tar, } \\
\quad \text { and dust }\end{array}$ & $\begin{array}{l}\text { Converting biomass } \\
\text { to biochar and } \\
\text { bio-oil }\end{array}$ & $\begin{array}{l}\text { Liquid fuels are produced } \\
\text { directly, and after appropriate } \\
\text { treatment, it can be directly } \\
\text { treated in conventional } \\
\text { refineries. }\end{array}$ \\
\hline Combustion & 700 to 1000 & $\geq 0.1$ & $\mathrm{CO}_{2}$ and $\mathrm{H}_{2} \mathrm{O}$ & $\begin{array}{c}\mathrm{SO}_{\mathrm{xy}}, \mathrm{NO}_{\mathrm{xy}}, \\
\text { polycyclic aromatic } \\
\text { hydrocarbons } \\
\text { (PAHs), and dust }\end{array}$ & $\begin{array}{c}\text { Converting biomass } \\
\text { to heat and } \\
\text { electricity }\end{array}$ & $\begin{array}{l}\text { The procedure is } \\
\text { straightforward. } \\
\text { Co-combustion of biomass and } \\
\text { coal does not necessitate any } \\
\text { changes to existing } \\
\text { power plants. }\end{array}$ \\
\hline Torrefaction & 200 to 300 & $\geq 0.1$ & $\mathrm{CO}_{2}, \mathrm{CO}$, and $\mathrm{CH}_{4}$ & $\begin{array}{l}\mathrm{H}_{2} \mathrm{~S}, \mathrm{COS}, \mathrm{CS}_{2} \\
\mathrm{NH}_{3} \text {, and } \mathrm{HCN}\end{array}$ & $\begin{array}{l}\text { Converting biomass } \\
\text { into coal-like } \\
\text { material }\end{array}$ & $\begin{array}{l}\text { Moisture reduction, energy } \\
\text { density increase, } \mathrm{O} / \mathrm{C} \text { ratio } \\
\text { reduction, and improved } \\
\text { ignitability and reactivity of the } \\
\text { processed fuel. }\end{array}$ \\
\hline $\begin{array}{l}\text { Hydrothermal } \\
\text { liquefaction }\end{array}$ & 250 to 550 & 5 to 25 & $\begin{array}{l}\mathrm{H}_{2}, \mathrm{CO}, \mathrm{CO}_{2} \\
\quad \text { and } \mathrm{CH}_{4}\end{array}$ & $\begin{array}{l}\text { Polypropylene (PE), } \\
\text { polypropene (PP), } \\
\text { and nylon-6 (NY) }\end{array}$ & $\begin{array}{l}\text { Converting wet } \\
\text { biomass into } \\
\text { crude-like oil }\end{array}$ & $\begin{array}{l}\text { Process is environmentally } \\
\text { friendly. The energy efficiency } \\
\text { of the HTL process is very high. }\end{array}$ \\
\hline
\end{tabular}

The most common thermochemical reactions are combustion, torrefaction, pyrolysis, liquefaction, and gasification. When comparing pyrolysis and gasification, the pyrolysis process has a lower reaction temperature than the gasification process. The material's volatile components are thermally decomposed into more syngas and non-volatile carbon char, which are by-products of the pyrolysis process. The drawback of torrefaction is that as the residence time increases, the hydrogen and oxygen composition of biomass decreases in contrast to carbon, resulting in a decrease in biomass volatile matter content. The liquefaction method has received a lot of attention for utilising biomass waste because of its flexibility and potential to be used as a construction medium for a final product that incorporates all of the positive functional groups present in the liquefying solvents and biomass. Compared to other thermochemical processes, liquefaction requires lower temperatures, allowing it to save more fuel, generate fewer pollutants, and be considerably less expensive.

\section{Thermal Analysis Technologies}

Biomass technology refers to the wide range of applications and flexibility of commodity gas that can be used to generate heat, power, and mechanical energy, which includes gas engines, gas turbines, and so on, as well as feedstock for the production of fuels and chemicals [64]. The ultimate distribution of the gas can influence not only the design and procurement of the most appropriate gasification and gas upgrading systems, but it will also influence the demands and challenges of gas analysis in the measurement facility [65]. 
The thermochemical process is a chemical reaction that converts carbonate elements into raw chemical substrates or gaseous fuels. It necessitates the use of a medium reaction, such as air, oxygen, subcritical steam, or certain gaseous mixtures. The determination of the commodity gas composition allows for the measurement of parameters such as the heating value and the Wobbe Index, which are important when using the gas for heat and power generation. In this segment, other compounds such as argon, neon, or helium, which are commonly used as tracer gases in lab-scale applications to conduct balance around the gasifier or downstream equipment, as well as oxygen and nitrogen will be considered [66]. Thermal analysis is a broad phrase that refers to a technology for determining the residence time and temperature at which physical changes in a substance occur when it is heated or cooled. Each technique, such as GC, TG, and DSC, is defined by the types of physical changes that are being investigated. Depending on the aim, several procedures or a mix of multiple technologies are required when evaluating material attributes. This chapter discusses the thermochemical conversion process as it relates to the principal finding technology in various analysis conditions.

\subsection{Gas Chromatography (GC)}

Gas chromatography (GC) is the most popular method for analysing fire residues. The term GC refers to a group of analytical separation technologies used to study volatile compounds in the gas phase [67]. Petroleum additives are used as accelerants in fires in most situations, and the peak trends from the GC study can be used to determine the type of fuel used in the burn. Drug processing is one of the first applications of GC in forensic science. GC will isolate and quantify a wide range of 'street' drugs. GC is used to test blood and other body fluids for medications and toxins after appropriate extraction procedures have been followed [68]. The analytical tool for substance identification is GC that requires a close connection with a mass spectrometer. The operation of a micro-GC is identical to that of a traditional GC, except that the various components are miniaturised in the micro-GC to improve portability, reduce power usage, and increase analysis speed.

Gas chromatography-mass spectrometry (GC-MS) incorporates the advantages of high-resolution component isolation with highly selective and efficient mass detection. It is common to use GCMS technologies for qualitative identification and the precise quantitative determination of unknown compounds [69]. The combination of the two technologies enables both qualitative and quantitative analyses of a sample containing a variety of organic compounds. Figure 4 shows a schematic diagram of the main components of a standard capillary GCMS device. The chromatograph's gaseous effluent is guided into the ion source through the transfer line. The vaporised analytes are first ionised, producing molecular and fragmented ions that are mass resolved and detected using a mass filter. The resulting mass continuum is graphed as a function of relative ion strength versus mass-to-charge ratio $(\mathrm{m} / \mathrm{z})[70]$.

Pyrolysis is known as the thermal transformation of one compound into another, which occurs in the absence of oxygen. In modern pyrolysis, sample decomposition is strictly regulated. Remember that pyrolysis gas chromatography is an indirect method of analysis in which heat is used to convert a compound into a sequence of volatile products that should be representative of the initial compound and the experimental condition. Pyrolysis-gas chromatography-mass spectrometry (Py-GC-MS) is one of the most widely used methods for analysing biomass activity during the flash pyrolysis process. A small volume of the examined sample is decomposed in a microreactor at a regulated heating rate. The use of a small sample weight reduces temperature latency during analysis and allows heating of biomass at rates of tens of thousands of ${ }^{\circ} \mathrm{C} / \mathrm{s}$, resulting in flash pyrolysis conditions. The chromatograms for a mixture of rapid pyrolysis products are extremely complicated. As a result, a mass spectrometer was combined with a gas chromatograph to classify a greater number of compounds produced during biomass decomposition [71]. The analysis of the collected mass spectra is often done using the National Institute of Standards and Technology Standard Reference (NIST) Mass Spectral (MS) library [72]. However, in 
some situations, data analysis problems could be noticed due to the low probability of the formation of compounds forming. As a result, a significant number of chromatographic peaks remain unidentified [73].

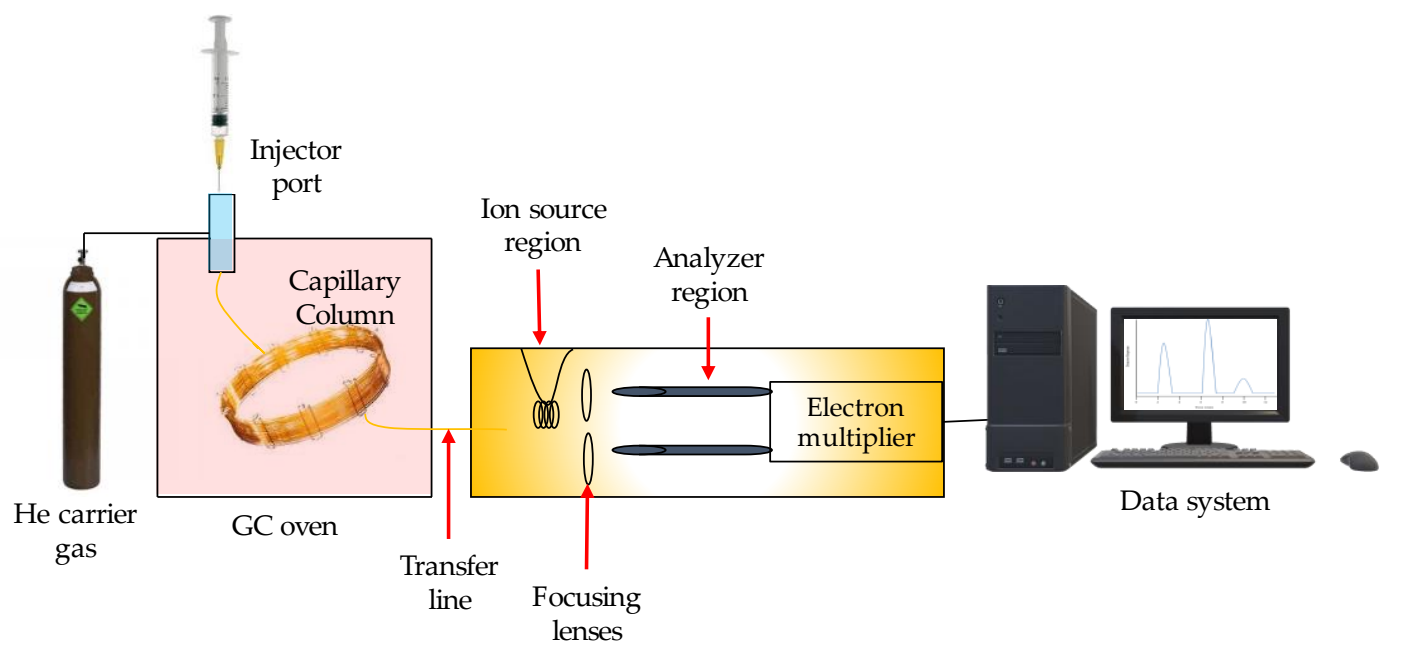

Figure 4. Schematic of GC-MS experimental analysis systems.

The total intensity of chromatographic peaks is usually calculated in the first phase of a Py-GC-MS experiment. Then, the detected compounds are classified into multiple classes based on chemical structure variations. The Py-GC-MS approach does not allow for the continuous execution of a procedure, which is one of the limitations of using Py-GC-MS to analyse rapid pyrolysis of biomass. According to the literature, the structure of the collected materials is very similar to that of other bench-scale pyrolysers. This process can be used to study the decomposition of lignocellulosic feedstock at high temperatures. Furthermore, PyGC-MS does not allow for the aggregation of formulated mixtures of reaction components, which are only collected for a short time in the adsorption column before being passed to the gas chromatograph for analysis [72]. For qualitative and quantitative evolved gas analysis (TGA), thermogravimetric analysis along with gas chromatography and mass spectrometry (TGA-GC-MS) is now the tool of preference. Thermal results can be combined with knowledge about the chemical origin, shape, and composition of material using this mixture of methods [74]. Both the TG and TC-MS start at the same time. Then, the GC-MS is operated in continuous mode with a set column temperature (e.g., $250{ }^{\circ} \mathrm{C}$ ) and short injection intervals. The developed gases are well-correlated with the TGA and DTG effects in terms of temperature and time. Along with the thermal analysis curves, the completed ion chromatogram can be viewed, measured, deposited, and exported. A signal for the start of the GC-MS run can be programmed in any temperature section [75]. For example, TGA-IST16-GC-MS was designed to determine the comonomer form and quality in a sequence of liner low-density polyethylene (LLDPE). It is faster and easier to conduct than conventional methods of extracting copolymer compositions, such as nuclear magnetic resonance or temperature-escalating elution fractionation (TREF) [76].

Two-dimensional gas chromatography $(\mathrm{GC} \times \mathrm{GC})$ is a well-established and sophisticated separation technique that consists of two columns connected by a modulator that transfers "slices" or fractions of each analyte peak from the first to the second column in a sequential manner. The two columns are often referred to as proportions, one dimensional and two dimensional, highlighting the fact that both serve as separate elution stages and thus are decoupled during the modulation phase. The one-dimensional column typically generates a sluggish elution chromatogram similar to that of a traditional GC analysis, whereas the two-dimensional column must analyse each transferred fraction in a proportionally shorter time frame. Each two-dimensional analysis usually takes 1 to $4 \mathrm{~s}$ to complete. Obtaining a modulation ratio (MR) at baseline for a primary peak width is the goal [77]. Figure 5 shows a diagram of the modulation system used to join the two 
columns. The computer program used to manage the data is available, but the application of GC $\times$ GC with a time-of-flight mass spectrometer gives a decent option when analysing mixtures of pure samples [78].

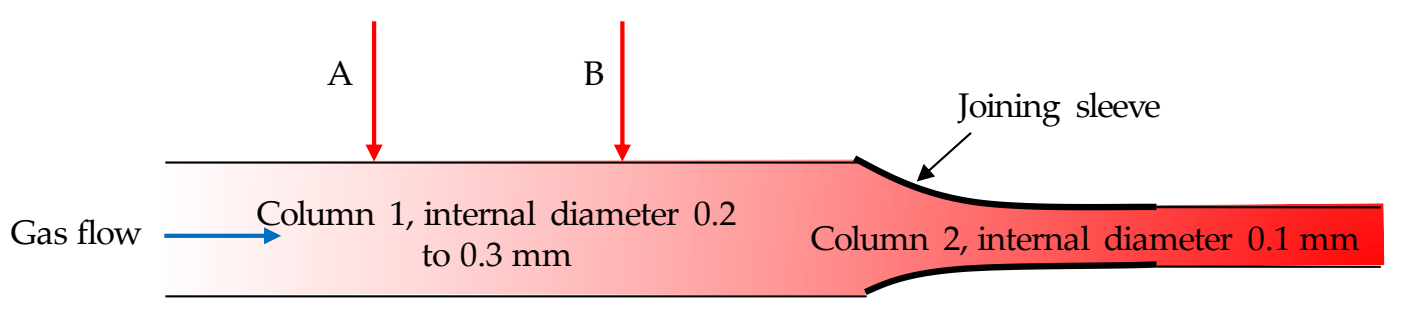

Figure 5. Schematic of GC $\times$ GC column joining and modulation.

The specific compounds within the most interesting subgroups are being investigated. In general, the study of GC studies and articles allows for the analysis of output efficiency. Then, the detected compounds are classified based on their chemical structure. Table 2 shows various approaches to the aforementioned division. The most common classes of studied compounds are hydrocarbons, phenols, carboxylic acids, aldehydes, alcohols, and ketones. Some researchers also use carbohydrates, esters, ethers, N-containing compounds, and other compounds. Some characterised substances are not assigned to any of the categories and are instead categorised as "others". This may be due to their dynamic composition or their inability to be identified.

Following that, Bouchra et al. [79] studied the maturity evaluation of compost from sewage sludge and green waste, focusing on effect of the presence of the composition of the biomass feedstock on the content of phenolic compounds, including phenol,4-methoxy, phenol, phenol,4-methyl, 2-methoxy-4-vinylphenol, phenol,3-ethyl, 4-vinylphenol, and benzene compounds (including benzene, ethyl benzene, dimethylbenzene, benzene, (1-methylethyl), benzene propyl, benzene,1-ethyl-2-methyl, benzene,1,2,4-trimethyl, benzene, propenyl, benzene,1-methyl-2-propyl, benzene, butyl, benzene,2-ethenyl-1,3-dimethyl, benzene, methyl (methylethenyl), benzene, hexyl, benzene, heptyl), cyclopentanones such as 2-cyclopeneten-1-one, 2-cyclopeneten-1-one,2-methyl, 2-cyclopenten-1-one,3-methyl, 2-cyclopenten-1-one,2,3-dimethyl, 2-cyclopenten-1-one,2-hydroxy,3-methyl, and only two furans compounds, including 2-furancarboxaldehyde and 2-furancarboxaldehyde,5-methyl. Maria et al. [80] studied the impact of the biomass diversity on the torrefaction process, which used the TGA-GC-MS technique to explore the composition of the kinetic behaviour of the European biomass.

The identification of the composition of the beech wood, which included 11 types of phenolic compounds, 7 types of aldehyde compounds, 10 types of ketones, and so on, is presented in Table 3. Table 4 shows the different types of gas chromatographic columns, conditions, and the key findings of the GCMS study of the biomass feedstock. EGA-GCMS is a technique for trapping gas generated in any EGA thermogram temperature range and performing GCMS measurement. Evolved gas analysis (EGA) is a mass spectrometry method that analyses temperature-resolved volatile species created from a sample placed within a microfurnace. The results of direct temperature-resolved mass spectrometry are similar to EGA curves, which appear as total ion current against temperature profiles (DTMS). However, with DTMS, the sample vapour is created directly within the mass spectrometer's source by the use of a heated filament, allowing for the detection of bigger mass fragments and improved labile compound detection [81]. Heart-cut analysis is a GCMS technique that selectively introduces compounds from any temperature zone in an EGA thermogram into a separation. This technology, which necessitates the use of a Selective Sampler and a Microjet Cryo-Trap, allows for automatic GC-MS analysis of up to eight temperature zones [82]. 
Table 2. The most popular groups of products formed in GC-MS experiments.

\begin{tabular}{|c|c|c|c|c|c|c|c|c|c|c|c|c|c|c|}
\hline \multirow{2}{*}{ Group } & \multicolumn{14}{|c|}{ Reference } \\
\hline & [83] & [84] & [79] & [74] & {$[80]$} & [85] & [86] & [87] & [88] & [89] & [90] & [91] & [92] & [6] \\
\hline Aldehydes & + & + & + & + & + & + & + & + & & + & & + & + & \\
\hline Acids & + & + & + & + & + & + & + & + & & + & + & + & + & \\
\hline Alcohols & + & + & & + & + & + & + & + & + & + & + & + & + & \\
\hline Anhydrosugars & + & + & & + & + & + & & & & + & & & & \\
\hline Carbohydrates & & + & + & & & + & + & & & & + & + & + & \\
\hline Ketones & + & + & + & + & + & + & + & + & + & + & & + & + & \\
\hline Hydrocarbons & + & + & + & & & + & & + & + & & + & + & + & \\
\hline Phenols & + & + & + & + & + & + & + & + & + & + & + & + & + & + \\
\hline Furans & + & & + & + & + & + & + & & + & + & & + & + & \\
\hline Esters & + & + & + & + & + & + & & + & & & + & + & & \\
\hline Ethers & + & + & & + & & + & & + & & + & & & & \\
\hline Pyrans & & + & + & + & + & + & & & & & & & & + \\
\hline N-compounds & & + & + & & & + & & & & & & + & + & \\
\hline Others & + & + & + & + & + & + & + & + & + & + & & + & + & + \\
\hline
\end{tabular}

Table 3. Composition of biomass feedstocks from various treatment processes.

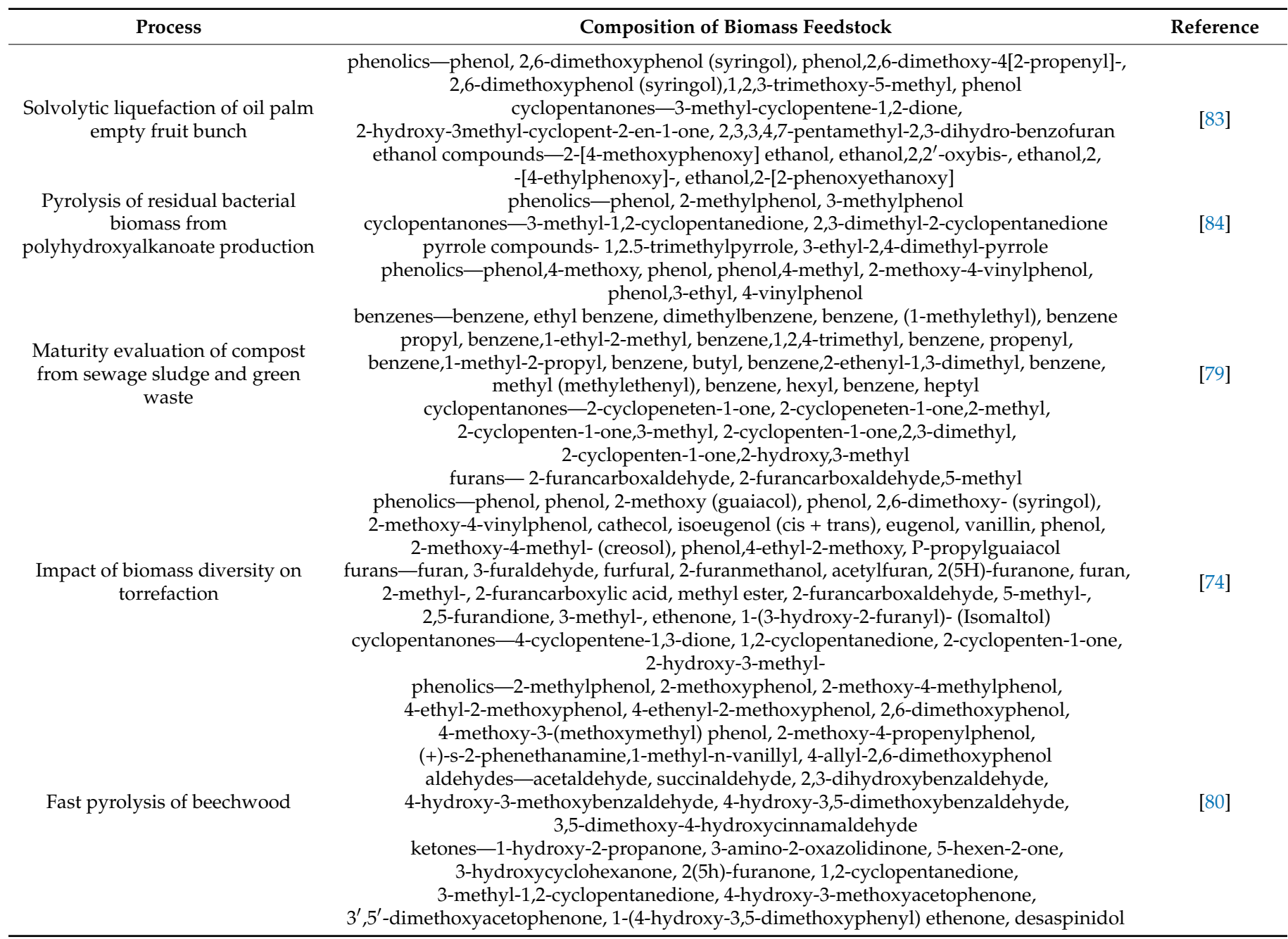


Table 4. The summary of the different gas chromatographs on the thermochemical conversion process of different types of biomass feedstocks.

\section{Biomass Feedstock

Technologies/Instrument \\ Chromatographic Analysis Conditions}

Micro-GC

Raw wood, and wood char

Sawdust pellets

Beech wood

EFB

Py-GC-MS (GC 6890 and

MSD 5973)

Py-GC-MS

Residual bacterial biomass

Chrella vulgaris

Micro-GC (INFICON, 3000)

GC-MS (Fison GC 8000/MD 800 system)

Temperature: 850,900 , and $950{ }^{\circ} \mathrm{C}$ Ratio feedstock to biomass:

(0:100, 20:80, 50:50, 80:20, and 100:0)

Temperature: $480{ }^{\circ} \mathrm{C}$ Ratio feedstock to biomass: $(10,20,40,80$, and $100 \%)$

Column: DB-1701 capillary column $(60 \mathrm{~m} \times 0.25 \mathrm{~mm} \times 0.25 \mathrm{~mm})$

Temperature: 45 to $245^{\circ} \mathrm{C}$

Gas: $1.0 \mathrm{~mL} / \mathrm{min}$ MS: $m / z 30$ to 300

Column: fused silica HP- 5 ms column

$(30 \mathrm{~m} \times 0.25 \mathrm{~mm} \times 25 \mu \mathrm{m})$

Temperature: $250{ }^{\circ} \mathrm{C}$

Gas: $1.0 \mathrm{~mL} / \mathrm{min}$

MS: no data

Column: RTx-5MS capillary column

(30 $\mathrm{m} \times 0.25 \mathrm{~mm} \times$ Restek)

Temperature: 40 to $250{ }^{\circ} \mathrm{C}$ Gas: no data

MS: no data

Column: ZB-WAX column

$(30 \mathrm{~m} \times 0.25 \mathrm{~mm} \times 0.25 \mu \mathrm{m})$

Temperature: $220^{\circ} \mathrm{C}$

Gas: $1.0 \mathrm{~mL} / \mathrm{min}$

MS: $m / z 20$ to 450

\section{Main Findings}

Reference

The gasification rate rises to optimum values, which

differ according to the coal-to-biomass ratio.

The average reactivity of the blended coal-biomass

char decreases as the proportion of coal in the blend

increases, and the impact of the coal appears to be

decreased at higher gasification temperatures.

The average heating at about $100{ }^{\circ} \mathrm{C} / \mathrm{min}$.

The biochar catalyst loading ratio to feedstock has an important impact on product yields

Based on the initial dry wood mass, the yield of char, total liquids, water, and gas were reported.

Total liquid yields range from 40 to $55 \%$ of dry wood.

It quantifies the amount of tar at around 40 to $43 \%$.

The HHV of EFB at around $18.69 \mathrm{MJ} / \mathrm{kg}$. Phenolic compounds are the most common compounds found in EFB. carbon dioxide being the most common, followed by acetic acid $(9.8 \%)$, docosenamide $(10.9 \%)$, and acetaldehyde $(9.1 \%)$.

Compounds extracted from carbohydrates (including acetic acid) accounted for $20 \%$.

The pyrolysis products were $\mathrm{N}$-containing compounds derived from protein, which accounted for around $36 \%$.

The 20 fatty acids were reported, with omega- 6 being the most prevalent and having a higher percentage of unsaturation

A total of 48 lipids have been identified and putatively annotated in the major clusters. 
Table 4. Cont.

\begin{tabular}{|c|c|c|c|c|}
\hline Biomass Feedstock & Technologies/Instrument & Chromatographic Analysis Conditions & Main Findings & Reference \\
\hline Five Indian coals & $\begin{array}{c}\text { Py-GC-MS (Agilent } 7890 \text { GC, } \\
\text { Agilent 5975C MS) }\end{array}$ & $\begin{array}{l}\text { Column: DB1701 } \\
(60 \mathrm{~m} \times 0.25 \mathrm{~mm} \times 0.25 \mu \mathrm{m}) \\
\text { Temperature: } 300{ }^{\circ} \mathrm{C} \\
\text { Gas: } 1.0 \mathrm{~mL} / \mathrm{min} \\
\text { MS: no data }\end{array}$ & $\begin{array}{l}\text { It is most suitable at temperature of } 650{ }^{\circ} \mathrm{C} \text { because of } \\
\text { the maximum breakdown of coal } \\
\text { structure associations. } \\
\text { In comparison with the OCs, the SCCs showed the low } \\
\text { region of the n-alkanes and alkenes. }\end{array}$ & [96] \\
\hline $\begin{array}{l}\text { Sewage sludge, and green } \\
\text { waste }\end{array}$ & $\begin{array}{c}\text { Py-GC-MS (Hewlett Packard } \\
\text { HP-6890) }\end{array}$ & $\begin{array}{l}\text { Column: Sol Gel Wax column } \\
(60 \mathrm{~m} \times 0.32 \mathrm{~mm} \times 0.5 \mu \mathrm{m}) \\
\text { Temperature: } 280^{\circ} \mathrm{C} \\
\text { Gas: } 1.0 \mathrm{~mL} / \mathrm{min} \\
\text { MS: } \mathrm{m} / \mathrm{z} 40 \text { to } 700\end{array}$ & $\begin{array}{c}\text { The concentration of lipid in sewage sludge }(58 \mathrm{mg} / \mathrm{g}) \\
\text { is higher than that in green waste }(16 \mathrm{mg} / \mathrm{g}) . \\
\text { The total peak area of nitrogenous compounds in } \\
\text { sewage sludge was } 334 \% \text {, compared to just } 93 \% \\
\text { in green waste. }\end{array}$ & [79] \\
\hline $\begin{array}{l}14 \text { types of European } \\
\text { biomasses }\end{array}$ & $\begin{array}{c}\text { TGA-GC-MS (TGA, 92-16.18 } \\
\text { SETARAM TGA 92) }\end{array}$ & $\begin{array}{l}\text { Column: three-plate crucible } \\
(10 \mathrm{~mm} \times 2 \mathrm{~mm}) \\
\text { Temperature: } 200 \text { to } 300{ }^{\circ} \mathrm{C} \\
\text { Gas: } 50 \mathrm{~mL} / \mathrm{min} \\
\text { MS: no data }\end{array}$ & $\begin{array}{l}\text { The final solid mass loss at the end of the dynamic } \\
\text { stage is between } 20 \text { to } 26 \% \text {, and between } 33 \text { and } 58 \% \\
\text { during the isothermal stage. } \\
\text { After torrefaction, the hydrogen content remained low } \\
\text { and had little impact. } \\
\text { At temperature below } 300^{\circ} \mathrm{C} \text {, furfural's production } \\
\text { profiles are at the peak. }\end{array}$ & [74] \\
\hline $\begin{array}{l}\text { Rice husk, chicken manure, } \\
\text { wood chip, coconut fibre, } \\
\text { maize straw, cotton straw, } \\
\text { and rice straw }\end{array}$ & $\begin{array}{c}\text { GC-MS (7890-5975C, Agilent } \\
\text { technologies) }\end{array}$ & $\begin{array}{l}\text { Column: HP-5MS chromatographic column } \\
\text { Temperature: } 60 \text { to } 300^{\circ} \mathrm{C} \\
\text { Gas: } 0.6 \mathrm{~mL} / \mathrm{min} \\
\text { MS: } m / z 30 \text { to } 500\end{array}$ & $\begin{array}{l}\text { Cotton straw has the highest gasification activity, and } \\
\text { the reaction takes } 5 \text { min to complete. } \\
\text { At temperature of } 900^{\circ} \mathrm{C} \text {, the gas composition of } \\
\text { biomass full gasification. } \\
\text { The amount of hydrogen is the highest, the amount of } \\
\text { methane is the lowest. }\end{array}$ & [87] \\
\hline Rice husk and PE pellets & $\begin{array}{c}\text { GC (Agilent, Micro GC, } \\
\text { 300A) }\end{array}$ & - & $\begin{array}{l}\text { The oxygenated compounds in biomass raw tars } \\
\text { become more difficult to crack as PE is added to } \\
\text { the feedstock. } \\
\text { The total gas of hydrogen and carbon monoxide yields, } \\
\text { particularly for a PE proportion of } 50 \text { and } 75 \% .\end{array}$ & [88] \\
\hline Imperata cylindica & $\begin{array}{l}\text { Py-GC-MS (CDS } 5200 \text { micro } \\
\text { pyrolser close-coupled), } \\
\text { (PerkinElmer Clarus } 680 \\
\text { GC), and (Clarus 600S MS) }\end{array}$ & $\begin{array}{l}\text { Column: PerkinElmer Elite- } 1701 \text { column } \\
\quad(30 \mathrm{~m} \times 0.25 \mathrm{~mm} \times 0.25 \mathrm{~mm}) \\
\text { Temperature: } 250^{\circ} \mathrm{C} \\
\text { Gas: } 50 \mathrm{~mL} / \mathrm{min} \text {, and a split ratio of } 50: 1 \\
\text { MS: no data }\end{array}$ & $\begin{array}{l}\text { The optimum number of components detected and the } \\
\text { percentage peak area are at } 500{ }^{\circ} \mathrm{C} \text {. } \\
\text { For } 400 \text { to } 600{ }^{\circ} \mathrm{C} \text {, the gas product increases from } 31.44 \\
\text { to } 35.96 \% \text { as the temperature increases. } \\
\text { If the temperature rises, the release of volatile matter } \\
\text { and secondary decomposition of bio-oil will increase. }\end{array}$ & [97] \\
\hline
\end{tabular}


Table 4. Cont.

\section{Biomass Feedstock}

\section{Technologies/Instrument}

Py-GC-MS (Frontier

Rice straw, cedar wood, and dalbergia wood Laboratories LTD, PY-3030D, Japan)

GC $\times$ GC-MS (Pegasus 4D System from Leco), and (Agilent 7890GC)

Algae biomass

Corn stalk

GC-MS (GCMS-QP2010 Ultra; Shimadzu)

Corn Stover
Py-GC-MS (Agilent 7890A/5975C)

\section{Chromatographic Analysis Conditions}

Column: DB-WAX

$(30 \mathrm{~m} \times 0.25 \mathrm{~mm} \times 0.25 \mu \mathrm{m})$

Temperature: $270{ }^{\circ} \mathrm{C}$

Gas: a split ratio of 1:40

MS: $m / z 35$ to 450

Column: Rxi-17SilMS

(Restek; $30 \mathrm{~m} \times 0.25 \mathrm{~mm} \times 0.25 \mu \mathrm{m}$ ) and SLB-5MS (Supelco; $1.5 \mathrm{~m} \times 0.1 \mathrm{~mm} \times 0.1 \mu \mathrm{m}$ )

Temperature: $280^{\circ} \mathrm{C}$

Gas: $1.2 \mathrm{~mL} / \mathrm{min}$ and a split ratio of 1:25 MS: no data

Column: RTX-5MS capillary column (Restek; $30 \mathrm{~m} \times 0.25 \mathrm{~mm} \times 0.25 \mu \mathrm{m})$ Temperature: 50 to $260^{\circ} \mathrm{C}$

Gas: $1.27 \mathrm{~mL} / \mathrm{min}$ and a split ratio of 100:1 MS: $m / z 35$ to 500

Column: HP-5MS capillary column

$(30 \mathrm{~m} \times 0.25 \mathrm{~mm} \times 0.25 \mu \mathrm{m})$ Temperature: no data

Gas: He- $1 \mathrm{~mL} / \mathrm{min}$ and a split ratio of 1:80 MS: $m / z 35$ to 550

\section{Main Findings}

Reference

Rice straw's high concentration of hemicellulose and cellulose resulted in a large number of acids and saccharides when pyrolysis at $270{ }^{\circ} \mathrm{C}$.

The content of levoglucosan of rice husk decreased as the temperature increase.

The concentration of alcohols in cedar wood decreased as the temperature increased.

Dalbergia wood has the highest lignin content compared to two other types of biomasses. The carbon and hydrogen content increase slightly

with proceeding hydrogenation (increasing temperature and/or residence time).

Hydrogen compounds classes are increases significantly, while heteroatomic compounds classes

$$
\text { decrease. }
$$

Using a traditional $\mathrm{NiMo} / \mathrm{Al}_{2} \mathrm{O}_{3}$ refinery catalyst, oxygen and nitrogen were reduced at temperatures ranging from 340 to $400{ }^{\circ} \mathrm{C}$ and pressures ranging from 238 to 253 bar.

The temperature of the pyrolysis reaction influences the types and yields of compounds formed by catalytic pyrolysis of biomass.

Total peak area increases as the pyrolysis temperature increased from 285 to $600{ }^{\circ} \mathrm{C}$; then, it dropped sharply at $700{ }^{\circ} \mathrm{C}$.

The coke yields of FZ, SZ, and RZ were followed by

$$
\text { (FZ > RZ > SZ). }
$$

RZ slightly promoted the production of phenols while SZ reduced the relative content of phenols 
Table 4. Cont.

\begin{tabular}{|c|c|c|c|c|}
\hline Biomass Feedstock & Technologies/Instrument & Chromatographic Analysis Conditions & Main Findings & Reference \\
\hline Soybean & $\begin{array}{c}\text { Py-GC-MS (CDS pyroprobe } \\
5250 \text { pyrolyzer), and (Trace } \\
\text { DSQII, Thermo Scientific, } \\
\text { USA) }\end{array}$ & $\begin{array}{c}\text { Column: TG-5MS capillary column } \\
(30 \mathrm{~m} \times 0.25 \mathrm{~mm} \times 0.25 \mu \mathrm{m}) \\
\text { Temperature: } 40 \text { to } 280^{\circ} \mathrm{C} \\
\text { Gas: He-1 mL/min and a split ratio of } 1: 40 \\
\text { MS: } \mathrm{m} / \mathrm{z} 45 \text { to } 650\end{array}$ & $\begin{array}{c}\text { Two-step pyrolysis's overall peak areas were all } \\
\text { smaller than those of one-step pyrolysis. } \\
\text { The volatile yield of one-step pyrolysis was increased } \\
\text { by using a higher pyrolysis temperature for } \\
\text { a longer time. }\end{array}$ & [92] \\
\hline Beechwood & $\begin{array}{c}\text { Py-GC-MS (CDS pyroprobe } \\
5200 \text { pyrolyser), and (Agilent } \\
7890 / 5975 C)\end{array}$ & $\begin{array}{c}\text { Column: HP5MS capillary column } \\
(30 \mathrm{~m} \times 0.25 \mathrm{~mm}) \\
\text { Temperature: } 50 \text { to } 300^{\circ} \mathrm{C} \\
\text { Gas: He-1 mL/min and a split ratio of } 1: 500 \\
\text { MS: } m / z 35 \text { to } 400\end{array}$ & $\begin{array}{l}\text { Beechwood contains } 45.8 \% \text { cellulose, } 31.8 \% \\
\text { hemicellulose, and } 21.9 \% \text { lignin. } \\
\text { The amount of carbon dioxide removed from pyrolysis } \\
\text { products decreases as the calcination temperature of } \\
\text { red mud catalyst increases. } \\
\text { For beechwood pyrolysis vapours, thermal } \\
\text { pre-treatment of red mud at } 950^{\circ} \mathrm{C} \text { was found to } \\
\text { be effective. }\end{array}$ & [80] \\
\hline Rice straw & $\begin{array}{l}\text { GCMS (GC, K8880181 by } \\
\text { ThermoFisher), (MS, DSQII } \\
\text { by Thermo Scientific), and } \\
\text { autosampler (ThermoFisher } \\
\text { AI 1310) }\end{array}$ & $\begin{array}{c}\text { Column: Rxi-5ms } \\
(30 \mathrm{~m} \times 0.25 \mathrm{~mm} \times 0.25 \mu \mathrm{m}) \\
\text { Temperature: } 35 \text { to } 275^{\circ} \mathrm{C} \\
\text { Gas: no data } \\
\text { MS: no data }\end{array}$ & $\begin{array}{l}\text { When the temperature of the torrefaction process } \\
\text { increase, the amount of pyrolysis bio-oil, gas, and } \\
\text { water decreased, as did the amount of char. } \\
\text { The torrefaction process helps in the improvement of } \\
\text { pyrolysis bio-oil production. } \\
\text { To optimise pyrolysis bio-oil recovery from rice straw, } \\
\text { a torrefaction temperature of } 225^{\circ} \mathrm{C} \text { with a pyrolysis } \\
\text { temperature of } 550^{\circ} \mathrm{C} \text { was suggested as the } \\
\text { optimum condition. }\end{array}$ & [86] \\
\hline Rice husk & $\begin{array}{c}\text { Py-GC-MS (Agilent } \\
\text { 7890GC/5975MS), and } \\
\text { commercialised pyrolyser } \\
\text { (no.5200, CDS Analytics Inc.) }\end{array}$ & $\begin{array}{l}\text { Column: HO-5MS capillary column } \\
(30 \mathrm{~m} \times 0.25 \mathrm{~mm} \times 0.25 \mu \mathrm{m}) \\
\text { Temperature: } 35 \text { to } 275^{\circ} \mathrm{C} \\
\text { Gas: He-1 mL/min and a split ratio of } 1: 80 \\
\text { MS: no data }\end{array}$ & $\begin{array}{l}\text { As the severity of torrefaction improved, the carbon } \\
\text { content increased, but the hydrogen and oxygen } \\
\text { contents decreased. } \\
\text { HHV were obtained as the carbon content of the } \\
\text { torrefied sample was increased. }\end{array}$ & [99] \\
\hline $\begin{array}{c}\text { Sunflower husk, oat husk, } \\
\text { wheat straw, miscanthus, } \\
\text { hay, wood chips, willow and } \\
\text { poplar }\end{array}$ & $\begin{array}{c}\text { Py-GC-MS (Shimadzu } \\
\text { GC-2010), and } \\
\text { (GC/MS-QP2010) }\end{array}$ & $\begin{array}{l}\text { Column: HO-5MS capillary column } \\
(30 \mathrm{~m} \times 0.25 \mathrm{~mm} \times 0.25 \mu \mathrm{m}) \\
\text { Temperature: } 85 \text { to } 145^{\circ} \mathrm{C} \\
\text { Gas: } 0.97 \mathrm{~mL} / \mathrm{min} \\
\text { MS: no data }\end{array}$ & $\begin{array}{l}\text { Different outcomes are obtained when wheat straw is } \\
\text { burned at temperatures ranging from } 350 \text { to } 450{ }^{\circ} \mathrm{C} \text {. } \\
\text { There are five chemicals produced when a greater } \\
\text { burning temperature }\left(4500^{\circ} \mathrm{C}\right) \text { is used. There were just } \\
\text { nine substances in the situation of combustion at a } \\
\text { lower temperature }\left(350^{\circ} \mathrm{C}\right) \text {. }\end{array}$ & [6] \\
\hline
\end{tabular}


Table 4. Cont.

\section{Biomass Feedstock}

\section{Technologies/Instrument}

EGA/PY-3030D

Fir and chestnut microfurnace pyrolyse

equipped with an UV-1047Xe

micro-UV-irradiator

Multi-Shot Pyrolyser EGA/Py-3030D

Wool

$$
\begin{aligned}
& \text { micro-furnace coupled to } \\
& 6890 \text { GC Agilent }
\end{aligned}
$$
Technologies

Pyrolysis-GCMS using a

Pyrolysis oil Shimadzu multi-functiona pyrolyser EGA/PY- 3030D

\section{Table 4. Cont.}

\section{Chromatographic Analysis Conditions}

Column: Ultra ALLOY capillary column

$$
\begin{gathered}
(30 \mathrm{~m} \times 0.25 \mathrm{~mm} \times 0.5 \mu \mathrm{m}) \\
\text { Temperature: } 280 \text { to } 550{ }^{\circ} \mathrm{C} \\
\text { Gas: no data }
\end{gathered}
$$

MS: $m / z 50$ to 600

Column: silica pre-column $(2 \mathrm{~m} \times 0.32 \mathrm{~mm}$ i.d., Agilent J\&W, USA) and HP-5MS fused capillary column $(30 \mathrm{~m} \times 0.25 \mathrm{~mm}$ i.d.,

Hewlett Packard, USA)

Temperature: 230 to $500{ }^{\circ} \mathrm{C}$ Gas: no data MS: $m / z 50$ to 600

Column: polydimethylsiloxane, UA1

$(30 \mathrm{~m} \times 0.25 \mathrm{~mm}$ i.d., $2 \mu \mathrm{m})$

Temperature: 300 to $500{ }^{\circ} \mathrm{C}$ Gas: $\mathrm{He}-50 \mathrm{~mL} / \mathrm{min}$

\section{Main Findings}

Reference

A shift in the relative intensities of holocellulose's $\mathrm{m} / \mathrm{z}$ signals.

The signals at $m / z 60$ and 73 increased, which is typical of levoglucosan, the main pyrolysis product of cellulose.

The primary process produces anhydro sugars by depolymerising holocellulose.

Fir wood showed significant changes, including an increase in the $\mathrm{H} / \mathrm{L}$ ratio and higher yields of both small molecules and anhydro sugars.

The presence of alkenes is caused by the radical breaking of the esters found in iso- and anteiso- fatty acids, which is caused by thermal degradation.

Working at low temperatures $\left(290^{\circ} \mathrm{C}\right)$ resulted in a pyro gram rich in diketopiperazines.

An increase in the amount of hydrogen in the pyrolysis oil and a decrease in the amount of oxygen.

$\mathrm{Mg}-\mathrm{Al}-\mathrm{LDO}$ has the highest deoxygenation rate MS: $m / z 50$ to 650

$$
\text { compared to all catalysts. }
$$

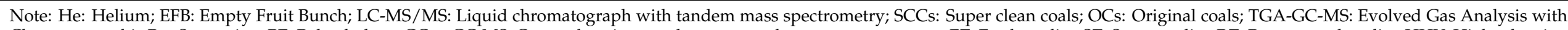

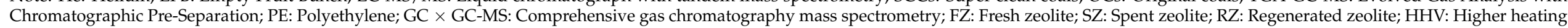
value; H/L: Holocellulose-to-lignin. 


\subsection{Thermogravimetric Analysers (TG)}

TG is an effective thermal study for gas-solid reactions. By varying process conditions, TGA is a form of thermal analysis that measures the mass of the sample over time or at a certain temperature in a controlled setting [103]. The sample can be analysed in a crescent or at an isothermal temperature, with the temperature gradually decreasing. There is a furnace, a microbalance, a temperature controller, and a data acquisition system included. A microbalance is used to weigh the mass of the sample as it is heated or cooled in the furnace according to a predetermined programme. This is a low-cost method that requires a limited sample size that allows quantitative or qualitative study. TGA is a fast and reliable tool. To detect thermal stability and weight reduction, a commercial TGA was used to thermally decompose milligram samples under monitored heating and environmental conditions in an atmosphere of air or inert nitrogen. In biopolymer films, TGA is a valuable instrument for testing the incorporation of nanoparticles and active compounds into biopolymer films or membranes by measuring the rise or decrease in thermal degradation peaks as well as determining the quickest or delayed thermal degradation [104].

With the addition of an infrared spectrometer to TGA, gases produced during sample degradation can be analysed and identified. The TGA system has a micro-furnace that can be quickly cooled. The heating unit is made of platinum and can withstand temperatures of up to $1000{ }^{\circ} \mathrm{C}$. The temperature range can be increased to $1500{ }^{\circ} \mathrm{C}$ by using an external furnace with a heating unit consisting of a platinum alloy containing 30\% rhodium. A modern apparatus will typically include a system that measures the weight-loss proportion or ratio. A commercial TGA has a temperature range of $1000^{\circ} \mathrm{C}$, a balance sensitivity of $0.1 \mu \mathrm{g}$, and a variable regulated heat-up rate in an atmosphere of air or another gas. TGA's heat-up intensity ranges from 0.1 to $200{ }^{\circ} \mathrm{C} / \mathrm{min}$ [105]. A TG generates a TGA curve and a differential thermogravimetric (DTG) curve, which can be used to calculate the maximum weight loss of biomass by differentiating the TGA curve. TGA may be performed in an inert or oxidative, or even vacuum environment. Figure 6 shows a schematic representation of the TGA.

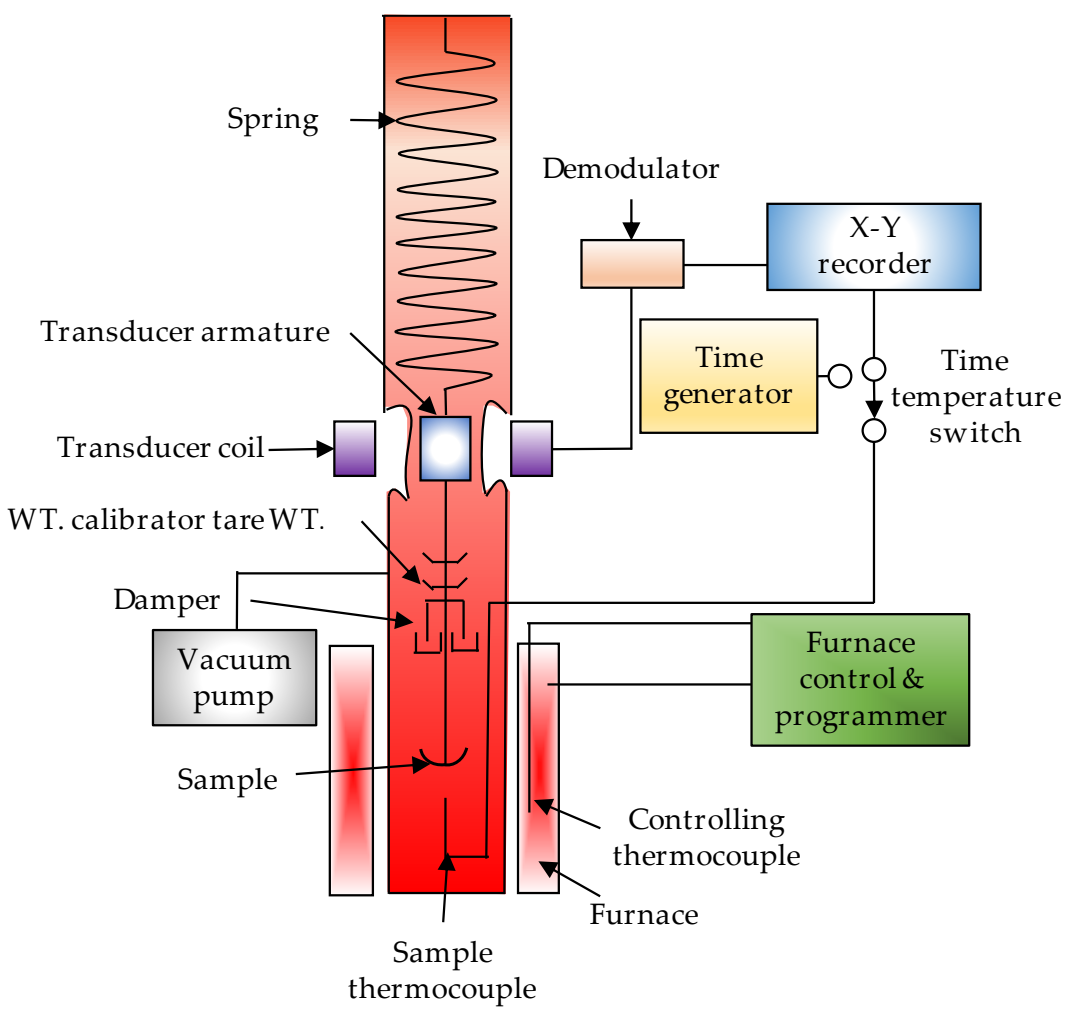

Figure 6. Schematic diagram of TGA along with different components. 
FTIR spectroscopy is based on the association of molecules with electromagnetic radiation in the mid-infrared spectral range of 4000 to $400 \mathrm{~cm}^{-1}$ [106]. Unlike MS, there is no ionisation, separation, or dissociation because the energy involved is insignificant. TGAFTIR integrates the power of TGA with the precision of FTIR substance characterisation and outgassing profiling. It reliably records the mass loss when a sample is heated up in the TGA analyser and detects the released molecular species as a result of the associated mass loss by passing the released molecular species through the FTIR instrument's long optical path glass cell [107]. When combined with TGA, FTIR may provide valuable information on the structure of gaseous compounds resulting from the combustion of solid fuels. In this analysis, TGA was used in conjunction with FTIR to investigate the combustion behaviour of all solid fuels and their blends as well as to calculate the emission of large gaseous contaminants of environmental significance at a constant heating rate. The TGA-FTIR scheme used in the current analysis is shown schematically in Figure 7. During the combustion cracking process, the gases emitted from the TGA were automatically swept to a gas cell, where they were analysed using FTIR. The result will be obtained from the gas volatilised during the thermal decomposition of biomass feedstock at various operating temperatures [108].

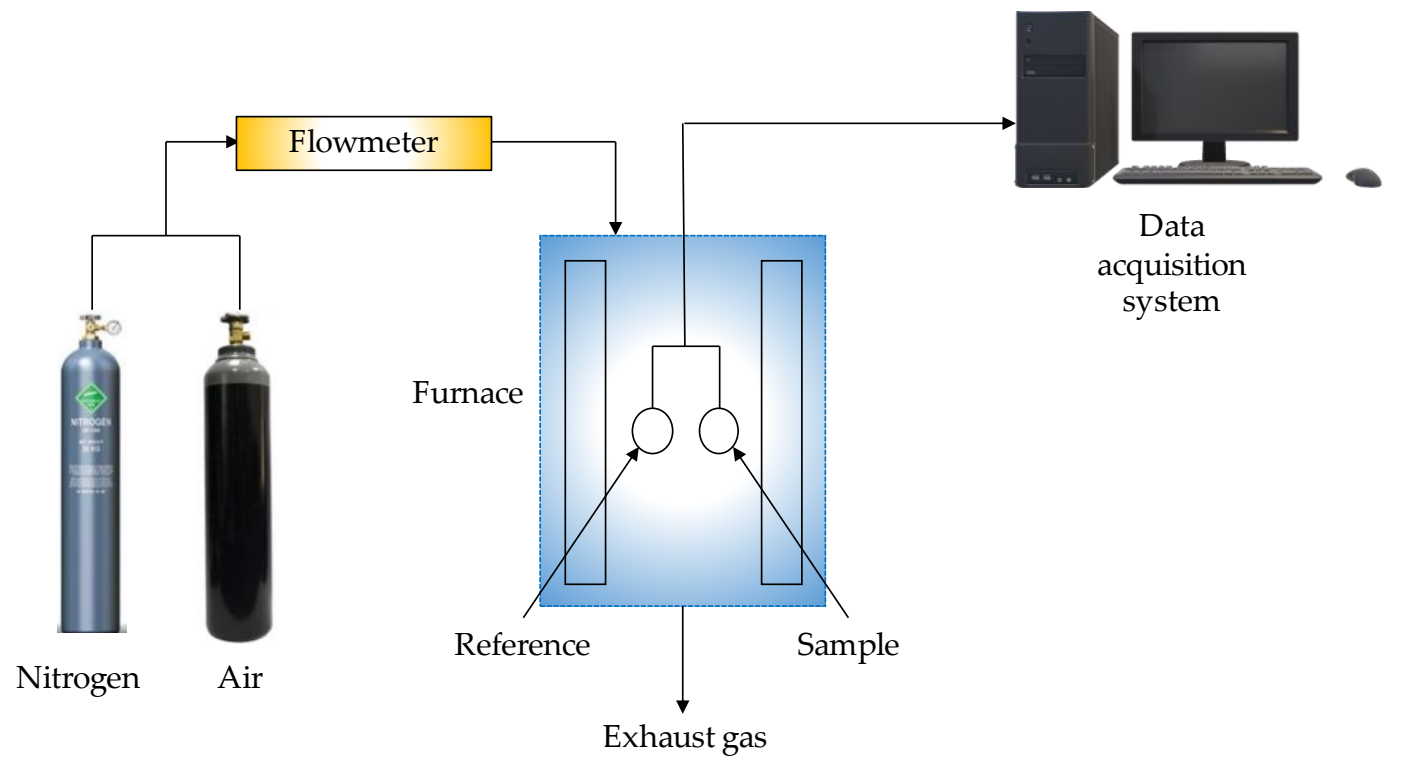

Figure 7. Schematic diagram of TGA-FTIR setup.

TGA-MS is an analytical technique used to identify small gaseous molecules such as $\mathrm{H}_{2} \mathrm{O}, \mathrm{HCL}$, or $\mathrm{CO}_{2}$, that are formed from simple samples. The MS is often used in conjunction with the TGA to detect and track the amplitude of one or more individual masses (e.g., 18, 28, and $44 \mathrm{~m} / \mathrm{z}$ ). This mode is highly sensitive and is also known as selected ion monitoring (SIM) or multiple ion detection (MID). The resulting $\mathrm{m} / z$ curve depicts the pressure of the chosen ion as a function of time. Peaks in the ion current signal for a given $\mathrm{m} / \mathrm{z}$ indicate the presence of molecules in the gas flow that can separate into ions with this mass-to-charge ratio after ionisation [106]. One popular application is the identification of residual solvents in pharmaceutical materials. In this analysis, the advanced gases from the TGA experiment are transferred online into the MS via a capillary tube. As a result, the precise temperature at which compounds emerge can be determined [109]. Combining TGA and MS allows for the structural recognition of compounds formed through thermal processes. The TGA off-gas is fed into MS, which is an analytical instrument that separates ions based on their mass-to-charge ratio using an electromagnetic field. Then, the ions are identified and transformed into mass spectra to classify the constituents expelled from the sample [110]. Figure 8 shows the TGA-MS concept diagram. Table 5 compares TG-MS and TF-FTIR in terms of advantages, limitations, and typical applications. Table 6 summarises 
the different biomass feedstocks used in the thermochemical process using the various TG methods.

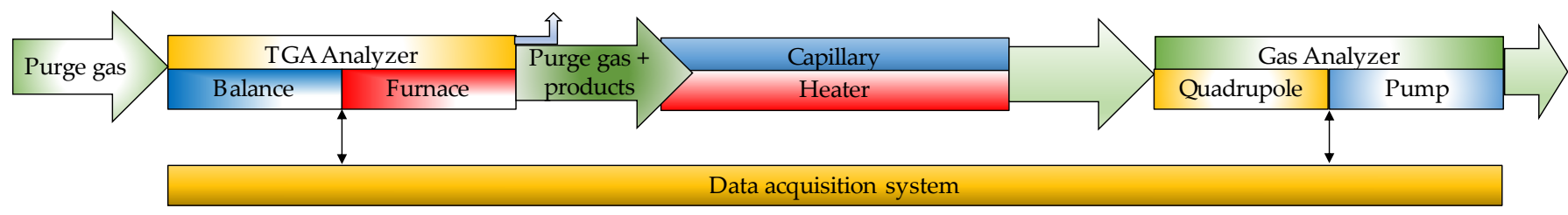

Figure 8. Schematic diagram of TGA-MS showing complete process.

Table 5. The comparison TG-MS and TG-FTIR.

\begin{tabular}{|c|c|c|c|}
\hline Technologies & Advantages & Limitations & Typical Applications \\
\hline MS & $\begin{array}{l}\text { Using online technology, the average } \\
\text { resolution is } 2^{\circ} \mathrm{C} \text {. } \\
\text { Dynamic susceptibility is high } \\
\text { ( }>5 \text { decades). } \\
\text { It is important to do a quantitative } \\
\text { analysis. }\end{array}$ & $\begin{array}{l}300 \text { amu is the maximum mass. } \\
\text { Data interpretation necessitates prior } \\
\text { knowledge of the dataset. } \\
\text { Big molecules will obstruct the gas } \\
\text { inlet (condensation). } \\
\text { The format of the data is incompatible } \\
\text { with that of other databases. }\end{array}$ & $\begin{array}{c}\text { Small molecule detection. } \\
\text { Active pharmaceutical } \\
\text { products and residual } \\
\text { solvents. }\end{array}$ \\
\hline FTIR & $\begin{array}{l}\text { Online technology with a standard } \\
\text { temperature resolution of } 2{ }^{\circ} \mathrm{C} \text {. } \\
\text { IT can also be used to analyse solids, } \\
\text { but a Fourier transform infrared } \\
\text { (ATR) accessory is needed (only iS50). } \\
\text { It also contains information on the } \\
\text { composition of the gases observed. }\end{array}$ & $\begin{array}{l}\text { Dynamic sensitivity is about } \\
3 \text { decades (DTGS detector). } \\
\text { Quantitative assessment can be } \\
\text { challenging. } \\
\text { Interpretation IR data necessitates } \\
\text { prior knowledge of the survey and } \\
\text { familiarity with it. } \\
\text { Not as responsive as MS or GC-MS. }\end{array}$ & $\begin{array}{l}\text { Clear and complicated } \\
\text { compound detection. } \\
\text { Active pharmaceutical } \\
\text { products and residual } \\
\text { solvents. }\end{array}$ \\
\hline
\end{tabular}


Table 6. The summary of the TGA on the thermochemical conversion process on different types of biomass feedstocks.

\begin{tabular}{|c|c|c|c|c|}
\hline Biomass Feedstock & Process/Technologies & Experimental Condition & Main Finding & Reference \\
\hline $\begin{array}{l}\text { Sewage sludge and } \\
\text { wheat straw }\end{array}$ & Co-pyrolysis (TGA) & $\begin{array}{c}\text { Final temperature: } 1000{ }^{\circ} \mathrm{C} \\
\text { Heating rate: } 20^{\circ} \mathrm{C} / \mathrm{min}\end{array}$ & $\begin{array}{l}\text { The yield of gas and liquid has increased, while the } \\
\text { yield of solid residue has decreased. } \\
\text { When the temperature increases, the gas yield } \\
\text { increases, but the liquid and char yields decrease. } \\
\text { Wheat straw percentages have a major impact on gas } \\
\text { composition and synergetic influence. }\end{array}$ & [111] \\
\hline $\begin{array}{c}\text { Zhundong lignite and } \\
\text { pine sawdust }\end{array}$ & Co-pyrolysis (TGA) & $\begin{array}{c}\text { Final temperature: } 900^{\circ} \mathrm{C} \\
\text { Heating rate: } 10,20,30 \text {, and } 40{ }^{\circ} \mathrm{C} / \mathrm{min}\end{array}$ & $\begin{array}{c}\text { Gas products increase while tar and char } \\
\text { yield decreased. } \\
\text { The condensable tar and non-condensable gases } \\
\text { increased gradually with the increasing temperature. }\end{array}$ & [112] \\
\hline Wheat straw and plastic & Co-pyrolysis (TGA) & $\begin{array}{c}\text { Final temperature: } 1100^{\circ} \mathrm{C} \\
\text { Heating rate: } 20^{\circ} \mathrm{C} / \mathrm{min}\end{array}$ & $\begin{array}{l}\text { With the temperature increase, the content of all } \\
\text { carbon-containing gas species normally decreases, } \\
\text { while the hydrogen content increases. } \\
\text { When char yield rises in non-sooty conditions, tar } \\
\text { yield falls. } \\
\text { Under sooty conditions, tar yields increase, and it will } \\
\text { affect soot particle size distribution. }\end{array}$ & [113] \\
\hline Woody biomass & Torrefaction (TGA) & $\begin{array}{l}\text { Temperature: } 225-300{ }^{\circ} \mathrm{C} \\
\text { Holding time: } 20,30 \text {, and } 40 \mathrm{~min}\end{array}$ & $\begin{array}{l}\text { For light, mild, and severe torrefaction, the maximum } \\
\text { devolatilisation rates were } 4.16,1.80 \text {, and } 0.70 \% / \mathrm{min} \text {, } \\
\text { respectively. }\end{array}$ & [114] \\
\hline Grape pomace & Torrefaction (TGA) & $\begin{array}{c}\text { Temperature: } 800^{\circ} \mathrm{C} \\
\text { Heating rate: } 10^{\circ} \mathrm{C} / \mathrm{min}\end{array}$ & $\begin{array}{l}\text { The energy values of raw and torrefied grape pomace } \\
\text { have } 84.9 \text { and } 85.2 \mathrm{~kJ} / \mathrm{mol} \text { in devolatilisation stage. } \\
\text { Torrefied grape pomace has higher nitrogen content } \\
\text { than raw biomass. } \\
\text { Torrefied grape pomace has a lower volatile content } \\
\text { and a higher fixed carbon content than raw biomass. }\end{array}$ & [115] \\
\hline $\begin{array}{l}\text { Wood biomass and brown } \\
\text { coal }\end{array}$ & Combustion (TGA) & Temperature: $1350^{\circ} \mathrm{C}$ & $\begin{array}{c}\text { Density of particulate matter (PM) from wood biomass } \\
\text { higher than brown coal. } \\
\text { Content of sulphur in PM brown coal at around } 0.398 \% \text {. } \\
\text { PM size distribution in dimensions between } \\
\qquad 20 \text { and } 100 \mu \mathrm{m} \text {. }\end{array}$ & [116] \\
\hline
\end{tabular}


Table 6. Cont

\begin{tabular}{|c|c|c|c|c|}
\hline Biomass Feedstock & Process/Technologies & Experimental Condition & Main Finding & Reference \\
\hline $\begin{array}{c}\text { Empty fruit bunch, rice husk, } \\
\text { coconut pulp, saw dust, } \\
\text { coconut shell, and sugar } \\
\text { cane bagasse }\end{array}$ & Pyrolysis (TGA) & $\begin{array}{l}\text { Final temperature: } 700{ }^{\circ} \mathrm{C} \\
\text { Heating rate: } 80^{\circ} \mathrm{C} / \mathrm{min}\end{array}$ & $\begin{array}{l}\text { The moisture content of saw dust is higher } 9.55 \mathrm{wt} \% \\
\text { than five biomass samples. } \\
\text { Saw dust has a lower HHV of } 17.03 \mathrm{MJ} / \mathrm{kg} \text { than other } \\
\text { five biomass samples. } \\
\text { Sugarcane bagasse has high thermal degradation rate } \\
\text { of } 0.0523 \mathrm{mg} / \mathrm{s} \text {. }\end{array}$ & [117] \\
\hline $\begin{array}{l}\text { Biomass wastes and digested } \\
\text { biomass wastes }\end{array}$ & Co-pyrolysis (TGA) & $\begin{array}{l}\text { Final temperature: } 850^{\circ} \mathrm{C} \\
\text { Heating rate: } 10,15 \text {, and } 20^{\circ} \mathrm{C} / \mathrm{min}\end{array}$ & $\begin{array}{l}\text { Increases in the proportion of microalgae in the blends } \\
\text { resulted in a decrease in activation energy value and a } \\
\text { rise in gas yields. } \\
\text { With an increase in the proposition of microalgae, the } \\
\text { evolution of carbon monoxide and carbon dioxide } \\
\text { decreased. }\end{array}$ & [118] \\
\hline Sugarcane Bagasse & Torrefaction (TGA-FTIR) & $\begin{array}{l}\text { Temperature: } 230,290^{\circ} \mathrm{C} \\
\text { Holding time: } 30 \mathrm{~min}\end{array}$ & $\begin{array}{l}\text { Reduction in the functionalities of hydrogen and } \\
\text { oxygen in the char as well as a 30\% rise in HHV. } \\
\text { When the temperature increases, the mass decreases; at } \\
\text { a temperature of } 290^{\circ} \mathrm{C} \text {, the maximum mass loss was } \\
2.6 \text { times faster. }\end{array}$ & [119] \\
\hline $\begin{array}{l}\text { Palm kernel shell with coal } \\
\text { bottom ash (CBA) }\end{array}$ & Gasification (TGA) & $\begin{array}{c}\text { Temperature: } 22.38,30,45,60 \text {, and } 66.20^{\circ} \mathrm{C} \\
\text { Gasifying agent: } \mathrm{CO}_{2}\end{array}$ & $\begin{array}{c}\text { When CBA was used as a catalyst in the TGA } \\
\text { gasification of palm kernel shell, it produced } 40.78 \text { vol } \\
\% \text { hydrogen. } \\
\text { The highest syngas composition at } 70.94 \mathrm{vol} \% \text { was } \\
\text { obtained when using CBA at } 45^{\circ} \mathrm{C} \text { for } 6.5 \mathrm{~h} \text { with an } \\
\mathrm{L} / \mathrm{s} \text { ratio of } 2.59 .\end{array}$ & [120] \\
\hline $\begin{array}{l}\text { Rice husk and petroleum } \\
\text { coke }\end{array}$ & Co-gasification (TGA) & $\begin{array}{l}\text { Temperature: } 360-545{ }^{\circ} \mathrm{C} \\
\text { Gasifying agent: } \mathrm{CO}_{2} \text { and } \mathrm{O}_{2}\end{array}$ & $\begin{array}{l}\text { The TGA curves change towards higher temperatures } \\
\text { as the heating rate is increased from } 10^{\circ} \mathrm{C} / \text { min to } 20 \\
\text { and } 30^{\circ} \mathrm{C} / \mathrm{min} \text {, but the overall form is retained. } \\
\text { With increasing the heating temperature, the pyrolysis } \\
\text { stage of the rice husk is slightly more sensitive than the } \\
\text { char gasification stage. } \\
\text { The maximum rate of degradation increased by } 7.66 \% \\
\text { with an increase in the heating rate from } \\
10 \text { to } 30^{\circ} \mathrm{C} / \mathrm{min} \text {. }\end{array}$ & [121] \\
\hline Wheat straw & Co-gasification (TGA-FTIR) & $\begin{array}{l}\text { Temperature: } 1050{ }^{\circ} \mathrm{C} \\
\text { Gasifying agent: } \mathrm{CO}_{2}\end{array}$ & $\begin{array}{l}\text { The maximum gasification rate changes as pre-treated } \\
\text { with varying temperatures. }\end{array}$ & [122] \\
\hline
\end{tabular}


Table 6. Cont.

\begin{tabular}{|c|c|c|c|c|}
\hline Biomass Feedstock & Process/Technologies & Experimental Condition & Main Finding & Reference \\
\hline Garden waste pellet and coal & Co-gasification (TGA) & $\begin{array}{l}\text { Temperature: } 690-900{ }^{\circ} \mathrm{C} \\
\text { Gasifying agent: } \mathrm{CO}_{2}\end{array}$ & $\begin{array}{l}\text { The reactivity of the gasification rate depends on the } \\
\text { biomass ratio. } \\
\text { The addition of biomass to coal steadily increased the } \\
\text { overall reactivity until the biomass ratio reached } 0.5 \text {. }\end{array}$ & [123] \\
\hline $\begin{array}{l}\text { Coal, pet coke, and olive } \\
\text { pomace }\end{array}$ & Co-gasification (TGA-MS) & $\begin{array}{l}\text { Temperature: } 105-1000{ }^{\circ} \mathrm{C} \\
\text { Heating rate: } 40{ }^{\circ} \mathrm{C} / \mathrm{min} \\
\text { Gasifying agent: } \mathrm{CO}_{2}\end{array}$ & $\begin{array}{c}\text { The binary blend containing dolomite has the highest } \\
\text { hydrogen per carbon monoxide ratio, the lowest } \\
\text { hydrogen sulphide, nitrogen oxide, and sulphur } \\
\text { dioxide emissions, and the highest synergetic } \\
\text { influence. }\end{array}$ & [124] \\
\hline Food waste & Torrefaction (TGA-FTIR) & $\begin{array}{c}\text { Temperature: } 225,275 \text {, and } 300^{\circ} \mathrm{C} \\
\text { Holding time: } 40 \mathrm{~min}\end{array}$ & $\begin{array}{l}\text { A rise in the rate of weight loss, with the maximum } \\
\text { peak at } 300^{\circ} \mathrm{C} \text {. } \\
\text { Torrefied food waste had a carbon content just } 5 \% \\
\text { lower than bituminous coal. } \\
\text { The lack of hydrogen due to the release of } \mathrm{H}_{2} \mathrm{O} \\
\text { explains the decrease in hydrogen content. }\end{array}$ & [125] \\
\hline Pine wood chips & Torrefaction (TGA) & $\begin{array}{l}\text { Temperature: } 250,300 \text {, and } 350{ }^{\circ} \mathrm{C} \\
\text { Heating rate: } 10,20 \text {, and } 40^{\circ} \mathrm{C} / \mathrm{min} \\
\text { Holding time: } 5,15 \text {, and } 30 \mathrm{~min}\end{array}$ & $\begin{array}{c}\text { The temperature and residence time increase, which } \\
\text { results in the volatile matter decreasing and the fixed } \\
\text { carbon increasing. } \\
\text { The atomic ratio of } \mathrm{O} / \mathrm{C} \text { and } \mathrm{H} / \mathrm{C} \text { decreased as } \\
\text { biomass was torrefied. } \\
\text { The average activation energy for } 300^{\circ} \mathrm{C} \text { with } 30 \mathrm{~min} \\
\text { biomass was } 183.40 \mathrm{~kJ} / \mathrm{mol} \text {, while the lowest value } \\
\text { was } 72.93 \mathrm{~kJ} / \mathrm{mol} \text { for } 350^{\circ} \mathrm{C} \text { with } 15 \mathrm{~min} \text { biomass. } \\
\text { Since the heating rate was raised from } 10,30 \text { and }\end{array}$ & [126] \\
\hline Palm kernel shell & Pyrolysis (TGA-FTIR) & $\begin{array}{c}\text { Final temperature: } 800^{\circ} \mathrm{C} \\
\text { Heating rate: } 10,30 \text {, and } 50^{\circ} \mathrm{C} / \mathrm{min}\end{array}$ & $\begin{array}{c}50^{\circ} \mathrm{C} / \text { min, the apparent activation energy increased. } \\
\text { The devolatilisation of cellulose and hemicellulose } \\
\text { played a major role in the weight loss. } \\
\text { The weight loss rate increased as the heating rate } \\
\text { increased at the same temperature. }\end{array}$ & [127] \\
\hline Cotton waste & Pyrolysis (TGA-FTIR) & $\begin{array}{l}\text { Final temperature: } 1000^{\circ} \mathrm{C} \\
\text { Heating rate: } 20^{\circ} \mathrm{C} / \mathrm{min}\end{array}$ & $\begin{array}{l}\text { The destruction of hemicellulose, cellulose, and lignin } \\
\text { occurs in increasing order of temperature during the } \\
\text { thermal decomposition of biomass. } \\
\text { At a temperature of } 311^{\circ} \mathrm{C} \text {, the highest peak indicates } \\
\text { the fastest rate of weight loss. }\end{array}$ & [128] \\
\hline
\end{tabular}


Table 6. Cont.

\section{Biomass Feedstock}

\section{Process/Technologies}

Experimental Condition

Final temperature: $700^{\circ} \mathrm{C}$

Sugarcane straw

Slow pyrolysis (TGA-FTIR)

Micactinium conductrix

Pyrolysis (TGA-MS) Heating rate: 10,15 , and $20^{\circ} \mathrm{C} / \mathrm{min}$

Final temperature: $900^{\circ} \mathrm{C}$ Heating rate: $20^{\circ} \mathrm{C} / \mathrm{min}$

\section{Corn brakes, wheat straw,} and hazelnut shell
Pyrolysis (TGA-MS)
Final temperature: $550^{\circ} \mathrm{C}$ Heating rate: 5,10 , and $20^{\circ} \mathrm{C} / \mathrm{min}$

\section{Main Finding}

Reference

During the pre-treatment period, approximately $6.4 \%$ of the mass of untreated SCS was lost.

As the heating rate increases, the peak corresponding to the maximum decomposition of the samples changes towards higher temperature.

When compared to untreated SCS pyrolysis, the

concentration of $\mathrm{CH}_{4}$ released by RCRM pyrolysis was higher.

With the lowest residual solid products, biomass harvested at MEP and LEP showed a higher degree of conversion or mass loss reaction through thermal degradation.

The thermal breaking of weak bonds in the polymetric structure is responsible for the maximum weight loss. When the heating rises, the intensity of the ion current rises as well, resulting in a higher rate of gas product release.

When changing the heating rate from the lowest to the maximum rate of heating, the $\mathrm{CO}$ evolution profile of

$$
\text { DTG maxima. }
$$

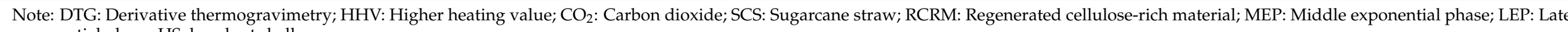
exponential phase; HS: hazelnut shell. 


\subsection{Differential Scanning Calorimetry (DSC)}

DSC is a thermoanalytical technique that uses a differential scanning calorimeter to analyse the thermal characteristics of a polymer. In this procedure, the difference in the amount of heat required to raise the temperature of a sample and a reference is calculated as a function of temperature. Throughout the experiment, the sample and reference will be kept at the same temperature. The DSC curve was found by plotting heat flux versus temperature or time. DSC is frequently used to determine the polymer breakdown behaviour [132]. DSC can be used to measure transitions such as glass transition, melting, and crystallisation. Chemical reactions can also be measured, such as thermal curing heat history, specific heat capacity, and purity analysis. The demand for thermal properties analysis has increased significantly in recent years because of the availability of highly useful polymeric materials. Although sublimation, evaporation, and thermal decomposition can all be monitored, this method is rarely used due to the mass change caused by decomposition and the sensor degradation caused by the decomposed gas.

The DSC is a commercially accessible instrument that is classified into two types: heat flux and power compensation. Figure 9 shows the Heat Flux DSC block diagram. The Heat Flux DSC is made up of sample and reference holders, a heat resistor, a heat sink, and a heater. Heat is transferred from the heater to the sample and reference through a heat sink and a heat resistor. The heat differential between the heat sink and the holders determines the heat flow. Compared to the sample, the heat sink has adequate heat capacity. When endothermic or exothermic phenomena, such as transition and reaction, occur in the sample, these phenomena are compensated by the heat sink [133]. A power-compensated DSC is frequently equipped with two control loops: an average temperature and a differential temperature loop. To guarantee that the average temperature matches the programmed temperature loop, equal power is applied to the sample and reference sides. Meanwhile, the differential control loop strives to minimise the temperature difference between the sample and reference sites [134]. A power-compensated DSC system is depicted schematically in Figure 10.

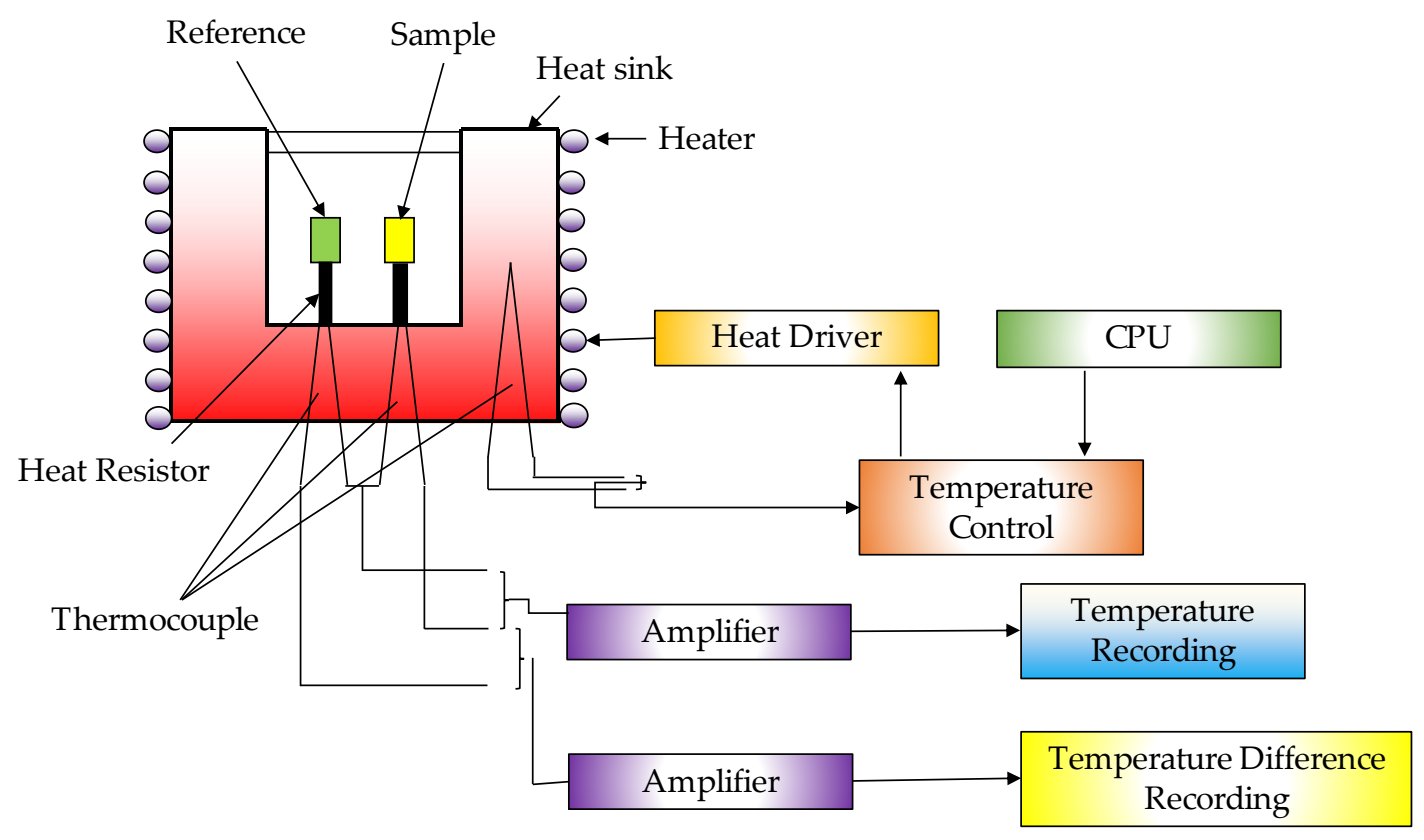

Figure 9. Process flow diagram of Heat Flux DSC. 


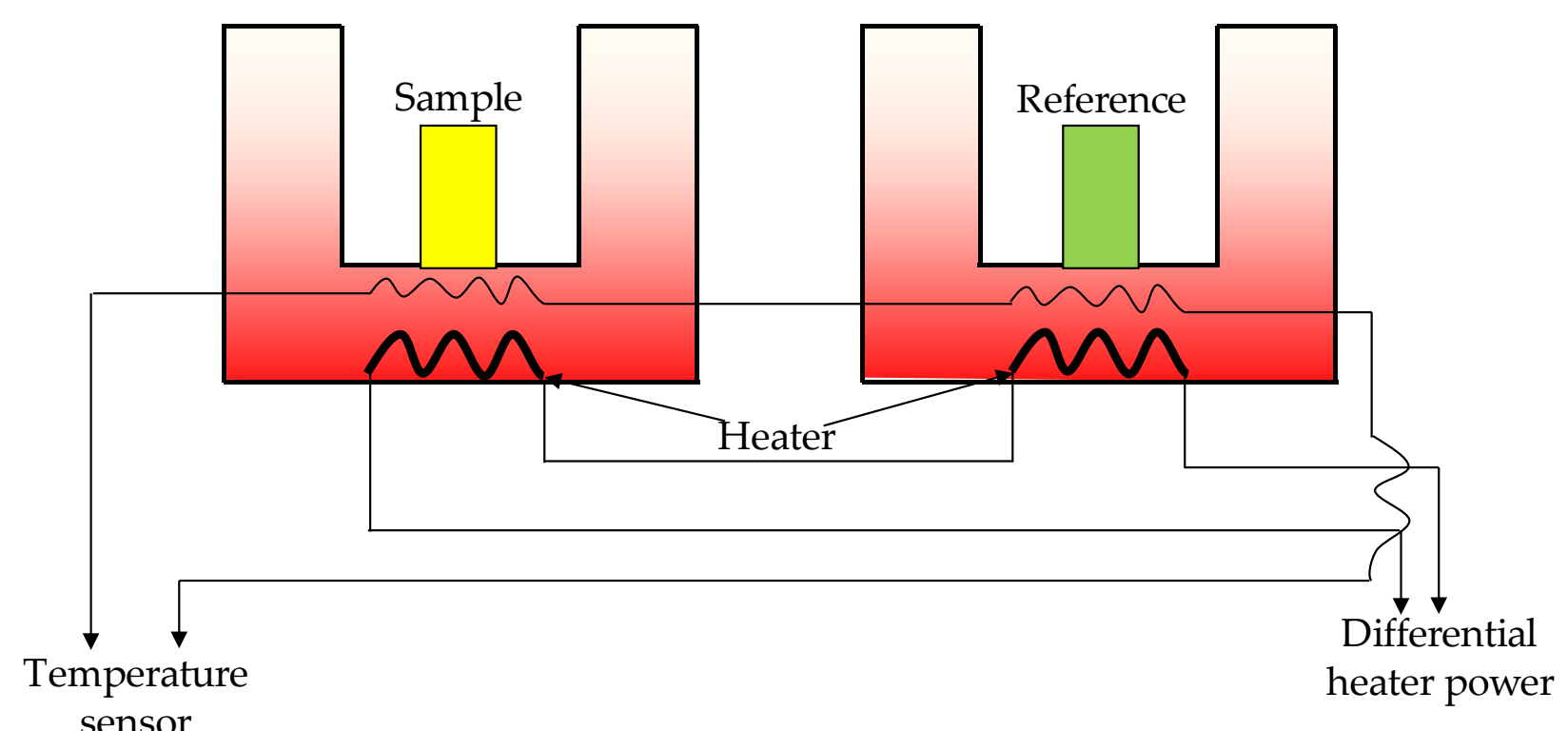

Figure 10. Schematic diagram of power-compensated DSC system.

The process is predominantly exothermal, according to the literature on HTC, with an enthalpy change of the order of $1 \mathrm{MJ}$ per $1 \mathrm{~kg}$ of dry biomass material [135]. Since the typical water/biomass ratio for biomass HTC ranges from 5 to 20, the separation of the thermal effect associated with the heating of water from that associated with the process is the main problem when dealing with the DSC measurements for the assessment of the enthalpy change of the HTC process. There are two basic procedures for dealing with this problem. The first step is to fill the reference crucible with the same amount of water as is used to moisten the dried substrate in the sample crucible. The second approach is based on the same theoretical foundation as the first, and it produces similar outcomes [136]. The diverse biomass feedstocks used in the HTC utilising the various DSC technologies are summarised in Table 7. 
Table 7. The summary of the DSC on the HTC process on different types of biomass feedstocks.

\section{Biomass Feedstocks}

Maia 200 F3 heat-flux DSC

Digestate and sludge

Maia 200 F3 heat-flux DSC

Cellulose, wood, and digestate

Maia 200F3, NETZSCH

Glucose, microcrystalline cellulose powder, and wood

Wheat straw, Miscanthus, and willow biomass species

DSC Analysis Conditions

Main Findings

Reference

Crucible: High-pressure titanium crucible

(100 $\mu \mathrm{L}$ capacity, 100 bar

maximum pressure)

Temperature: 156 to $476{ }^{\circ} \mathrm{C}$

Gas: $100 \mathrm{~mL} / \mathrm{min}$

Heating rate: $5^{\circ} \mathrm{C} / \mathrm{min}$

Crucible: High-pressure titanium crucible

(100 $\mu$ L capacity, 100 bar maximum pressure)

Temperature: 190 to $250{ }^{\circ} \mathrm{C}$

Gas: 50 and $100 \mathrm{~mL} / \mathrm{min}$

Heating rate: $5^{\circ} \mathrm{C} / \mathrm{min}$

Crucible: High-pressure titanium crucible

(100 $\mu \mathrm{L}$ capacity, 100 bar

maximum pressure)

Temperature: 156 to $476{ }^{\circ} \mathrm{C}$ Gas: No data

Heating rate: $5^{\circ} \mathrm{C} / \mathrm{min}$

Crucible: Pressure capsules $(30 \mu \mathrm{L})$

Temperature: $105^{\circ} \mathrm{C}$

Gas: No data

Heating rate: No data

Crucible: High-pressure DSC pan

Temperature: 50 to $320^{\circ} \mathrm{C}$

Gas: No data

Heating rate: No data
For wood and digestate, the heat release was highest at the beginning, whereas for cellulose, it was highest after $50 \mathrm{~min}$, and then all three curves converged to

$$
\text { zero with time. }
$$

The most energy was released by cellulose, owing to the exothermic carboxylation reaction.

Regarding the quantity and nature of the products created during the first run, the higher the HTC process temperature, the more gas is produced resulting in a bigger endothermic effect on heat flow ES.

The activation energies for digestate and sludge are 139.16 and $161.68 \mathrm{~kJ} / \mathrm{mol}$, respectively.

The presence of hemicellulose in wood, HTC enthalpy emission in wood, and digestate began at a lower temperature.

The decreased activity of lignin at $250{ }^{\circ} \mathrm{C}$ accounts for the lower enthalpy of wood in comparison to cellulose.

Most of the heat is dissipated between 30 and $40 \mathrm{~min}$ for cellulose and wood, while it takes longer for cellulose.

At a $\mathrm{pH}$ of 3 , adding acetic and formic acid had no effect on the kinetics of the heat effects.

A temperature scan of totally dry wheat straw revealed two separate exotherm peaks at 250 and $280{ }^{\circ} \mathrm{C}$.

The hemicellulose exotherm shifts downward as a result of hydration. 


\section{Comparison of Application on TG, DSC, and GC}

Temperature regulation, data collection, and analysis are all computer-assisted processes. The combination of the furnace and the sensor allows the use of a variety of measuring techniques. This computer can be linked to various pieces of equipment that use various measurement methodologies, allowing for simultaneous measurement and analysis. Table 8 compares the properties and phenomena of DSC and TG.

Table 8. Comparison property and phenomenon between DSC and TG.

\begin{tabular}{ccc}
\hline \multirow{2}{*}{ Phenomenon/Property } & \multicolumn{3}{c}{ Technologies } \\
\cline { 2 - 3 } & DSC & TG \\
\hline Melting & + & - \\
\hline Glass transition & + & - \\
\hline Crystallisation & + & - \\
\hline $\begin{array}{c}\text { Reaction } \\
\text { (Curing/Polymerisation) }\end{array}$ & + & + \\
\hline Sublimation/Evaporation/Dehydration & + & + \\
\hline Thermal decomposition & + & + \\
\hline Thermal history & + & - \\
\hline Specific heat capacity & + & - \\
\hline Property & Enthalpy & Mass \\
\hline Note: + = measurement object; $-=$ not measured.
\end{tabular}

Note: + = measurement object; $-=$ not measured.

The degradation behaviours of the biomass feedstocks were determined using TGA, while the product compositions of the biomass feedstocks were detected using Py-GC-MS. TGA may also be used to characterise compounds that are not appropriate for Py-GCMS, such as stable residues left over from pyrolysis [141]. Table 9 compares TG and GC applications.

Table 9. The comparison between TG and GC along with different applications.

\begin{tabular}{cl}
\hline Technologies & \multicolumn{1}{c}{ Applications } \\
\hline Micro-GC & A gas detector collection was used to assess the permanent gas composition. \\
\hline & The analysis of metabolites. \\
& Lipophilic compounds are detected. \\
& Aromatic amines that are biologically essential are examined. \\
& Application to human dosimetry. \\
& Acidic phytohormones and associated compounds are analysed in a single-run sensitive and \\
& quantitative manner. \\
& Detection of a toxic compound. \\
& Pyrethroid residues in vegetable samples need to be determined. \\
& Pesticides in foodstuffs are investigated. \\
& Applications in the environment and forensics unclassified. \\
& Most materials, such as insoluble and complex materials, can be characterised at trace levels without \\
& any sample pre-treatment. \\
& Investigate the structure of difficult-to-solve polymer compounds, investigate resin, degradation, and \\
study volatile additives.
\end{tabular}


Table 9. Cont.

\begin{tabular}{cl}
\hline Technologies & \multicolumn{1}{c}{ Applications } \\
\hline \multirow{2}{*}{ TGA } & $\begin{array}{l}\text { The assessment of degradation patterns and the composition of reaction kinetics was used to } \\
\text { characterise products. } \\
\text { Moisture content, volatile matter, ash content, and fixed carbon content are all measured using } \\
\text { proximate analysis. } \\
\text { Since each component's thermal decomposition temperature is different, it can quantitatively } \\
\text { overcome complex mixtures. } \\
\text { Identifying the amount of water or residual solvents in a substance. }\end{array}$ \\
\hline TGA-FTIR & $\begin{array}{l}\text { Determine the compounds and the functional groups of substances that characterise them. } \\
\text { This method is suitable for measuring compounds with medium to high infrared absorption. }\end{array}$ \\
\hline TGA-MS & $\begin{array}{l}\text { To detect very tiny quantities of substances. } \\
\text { This method is suitable for determining the properties of volatile compounds. }\end{array}$ \\
\hline DSC & $\begin{array}{l}\text { To calculate enthalpy changes as a function of temperature or time owing to changes in a material's } \\
\text { physical and chemical characteristics. } \\
\text { DSC is quick, accurate, and simple to use. }\end{array}$ \\
\hline
\end{tabular}

Lin et al. [142] discovered a similar relationship between weight loss from Py-GC-MS and TGA, which used different sample dosages and heating rates. This means that the weight loss observed in TG research will be mirrored to a large degree in quick pyrolysis. Given the wide range of heating rates, the degree of this relatively similar correspondence is remarkable.

\section{Conclusions}

The thermal analysis of the composition of biomass feedstock generated in thermochemical processes has many phases. Several compounds are produced during the thermal decomposition and have varying chemical properties of the lignocellulosic feedstock. GC and TGA are still the most commonly used methods for thermal analysis of biomass materials, despite their flaws. It stems from the technique's high flexibility and ability to screen quickly the composition. The study revealed that GC $\times$ GC may provide more precise knowledge on the contribution on specific chemical compounds. Finally, the rapid advancement of analytical techniques and data processing methods can broaden the spectrum of multivariate analysis applications, which can be useful especially in determining the composition of complex matrices with many different components.

Author Contributions: Conceptualisation, J.S.T.; Software, J.S.T. and Y.H.T.; Validation, J.S.T. and Y.H.T.; Formal analysis, J.S.T.; Resources, J.S.T. and Y.H.T.; Writing—original draft preparation, J.S.T. and Y.H.T.; Writing-review and editing, Y.H.T., H.G.H. and F.S.; Visualisation, J.S.T., Y.H.T. and F.S.; supervision, Y.H.T., and H.G.H.; Project administration, J.S.T. and Y.H.T.; Funding acquisition, Y.H.T. and F.S. All authors have read and agreed to the published version of the manuscript.

Funding: This research received no external funding.

Institutional Review Board Statement: Not applicable.

Informed Consent Statement: Not applicable.

Data Availability Statement: Not applicable.

Acknowledgments: This study was supported and acknowledged to Ministry of Higher Education Malaysia for Fundamental Research Grant Scheme with Project Code: FRGS/1/2019/TK07/USM/03/3 and Universiti Sains Malaysia Research University (RUI) Grant Scheme, 1001.PMEKANIK.8014136.

Conflicts of Interest: The authors declare no conflict of interest. 


\section{References}

1. Abokyi, E.; Appiah-Konadu, P.; Abokyi, F.; Oteng-Abayie, E.F. Industrial growth and emissions of $\mathrm{CO}_{2}$ in $\mathrm{Ghana}^{\mathrm{T}} \mathrm{The}$ role of financial development and fossil fuel consumption. Energy Rep. 2019, 5, 1339-1353. [CrossRef]

2. Charles Rajesh Kumar, J.; Majid, M.A. Renewable energy for sustainable development in India: Current status, future prospects, challenges, employment, and investment opportunities. Energy Sustain. Soc. 2020, 10, 1-36. [CrossRef]

3. Chen, W.H.; Peng, J.; Bi, X.T. A state-of-the-art review of biomass torrefaction, densification and applications. Renew. Sustain. Energy Rev. 2015, 44, 847-866. [CrossRef]

4. Sharma, A.; Jakhete, A.; Sharma, A.; Joshi, J.B.; Pareek, V. Lowering greenhouse gas (GHG) emissions: Techno-economic analysis of biomass conversion to biofuels and value-added chemicals. Greenh. Gases Sci. Technol. 2019, 9, 454-473. [CrossRef]

5. Pandey, B.; Prajapati, Y.K.; Sheth, P.N. Recent progress in thermochemical techniques to produce hydrogen gas from biomass: A state of the art review. Int. J. Hydrogen Energy 2019, 44, 25384-25415. [CrossRef]

6. Roman, K.; Barwicki, J.; Hryniewicz, M.; Szadkowska, D.; Szadkowski, J. Production of electricity and heat from biomass wastes using a converted aircraft turbine ai-20. Processes 2021, 9, 364. [CrossRef]

7. Ong, H.C.; Chen, W.H.; Singh, Y.; Gan, Y.Y.; Chen, C.Y.; Show, P.L. A state-of-the-art review on thermochemical conversion of biomass for biofuel production: A TG-FTIR approach. Energy Convers. Manag. 2020, 209, 112634. [CrossRef]

8. Bahng, M.K.; Mukarakate, C.; Robichaud, D.J.; Nimlos, M.R. Current technologies for analysis of biomass thermochemical processing: A review. Anal. Chim. Acta 2009, 651, 117-138. [CrossRef]

9. Pang, S. Advances in thermochemical conversion of woody biomass to energy, fuels and chemicals. Biotechnol. Adv. 2019, 37, 589-597. [CrossRef]

10. Cai, J.; Xu, D.; Dong, Z.; Yu, X.; Yang, Y.; Banks, S.W.; Bridgwater, A.V. Processing thermogravimetric analysis data for isoconversional kinetic analysis of lignocellulosic biomass pyrolysis: Case study of corn stalk. Renew. Sustain. Energy Rev. 2018, 82, 2705-2715. [CrossRef]

11. Cai, J.; He, Y.; Yu, X.; Banks, S.W.; Yang, Y.; Zhang, X.; Yu, Y.; Liu, R.; Bridgwater, A.V. Review of physicochemical properties and analytical characterization of lignocellulosic biomass. Renew. Sustain. Energy Rev. 2017, 76, 309-322. [CrossRef]

12. Niu, S.; Zhou, Y.; Yu, H.; Lu, C.; Han, K. Investigation on thermal degradation properties of oleic acid and its methyl and ethyl esters through TG-FTIR. Energy Convers. Manag. 2017, 149, 495-504. [CrossRef]

13. Arabi, M.; Ostovan, A.; Bagheri, A.R.; Guo, X.; Wang, L.; Li, J.; Wang, X.; Li, B.; Chen, L. Strategies of Molecular Imprinting-Based Solid-Phase Extraction Prior to Chromatographic Analysis; Elsevier B.V.: Amsterdam, The Netherlands, 2020.

14. Naik, P. Analytical Techniques in Biochemistry; Springer: New York, NY, USA, 2016; p. 624. [CrossRef]

15. Chan, Y.H.; Cheah, K.W.; How, B.S.; Loy, A.C.M.; Shahbaz, M.; Singh, H.K.G.; Yusuf, N.R.; Shuhaili, A.F.A.; Yusup, S.; Ghani, W.A.W.A.K.; et al. An overview of biomass thermochemical conversion technologies in Malaysia. Sci. Total Environ. 2019, 680, 105-123. [CrossRef] [PubMed]

16. Abdulrazik, A.; Elsholkami, M.; Elkamel, A.; Simon, L. Multi-products productions from Malaysian oil palm empty fruit bunch (EFB): Analyzing economic potentials from the optimal biomass supply chain. J. Clean. Prod. 2017, 168, 131-148. [CrossRef]

17. Rauch, R.; Hrbek, J.; Hofbauer, H. Biomass gasification for synthesis gas production and applications of the syngas. Wiley Interdiscip. Rev. Energy Environ. 2014, 3, 343-362. [CrossRef]

18. Katsaros, G.; Pandey, D.S.; Horvat, A.; Aranda Almansa, G.; Fryda, L.E.; Leahy, J.J.; Tassou, S.A. Experimental investigation of poultry litter gasification and co-gasification with beech wood in a bubbling fluidised bed reactor-Effect of equivalence ratio on process performance and tar evolution. Fuel 2020, 262, 116660. [CrossRef]

19. Phillips, D.; Mitchell, E.J.S.; Lea-Langton, A.R.; Parmar, K.R.; Jones, J.M.; Williams, A. The use of conservation biomass feedstocks as potential bioenergy resources in the United Kingdom. Bioresour. Technol. 2016, 212, 271-279. [CrossRef]

20. Boerrigter, H.; Rauch, R. Review of applications of gases from biomass gasification. ECN Biomass Coal Environ. $2006,20,33$.

21. Zhang, Y.; Zhao, Y.; Gao, X.; Li, B.; Huang, J. Energy and exergy analyses of syngas produced from rice husk gasification in an entrained flow reactor. J. Clean. Prod. 2015, 95, 273-280. [CrossRef]

22. Okolie, J.A.; Nanda, S.; Dalai, A.K.; Berruti, F.; Kozinski, J.A. A review on subcritical and supercritical water gasification of biogenic, polymeric and petroleum wastes to hydrogen-rich synthesis gas. Renew. Sustain. Energy Rev. 2020, $119,109546$. [CrossRef]

23. Ozturk, M.; Dincer, I. Integrated Gasification Combined Cycles; Comprehensive Energy System: Oshawa, ON, Canada, 2018; pp. 364-473. [CrossRef]

24. Kamble, A.D.; Saxena, V.K.; Chavan, P.D.; Mendhe, V.A. Co-gasification of coal and biomass an emerging clean energy technology: Status and prospects of development in Indian context. Int. J. Min. Sci. Technol. 2019, 29, 171-186. [CrossRef]

25. Guan, G.; Kaewpanha, M.; Hao, X.; Abudula, A. Catalytic steam reforming of biomass tar: Prospects and challenges. Renew. Sustain. Energy Rev. 2016, 58, 450-461. [CrossRef]

26. Ren, J.; Cao, J.P.; Yang, F.L.; Zhao, X.Y.; Tang, W.; Cui, X.; Chen, Q.; Wei, X.Y. Layered uniformly delocalized electronic structure of carbon supported Ni catalyst for catalytic reforming of toluene and biomass tar. Energy Convers. Manag. 2019, 183, 182-192. [CrossRef]

27. Liu, N.A.; Fan, W.; Dobashi, R.; Huang, L. Kinetic modeling of thermal decomposition of natural cellulosic materials in air atmosphere. J. Anal. Appl. Pyrolysis 2002, 63, 303-325. [CrossRef] 
28. Xu, C.; Hu, S.; Xiang, J.; Zhang, L.; Sun, L.; Shuai, C.; Chen, Q.; He, L.; Edreis, E.M.A. Interaction and kinetic analysis for coal and biomass co-gasification by TG-FTIR. Bioresour. Technol. 2014, 154, 313-321. [CrossRef] [PubMed]

29. Seo, Y.-C.; Alam, M.T.; Yang, W.-S. Gasification of Municipal Solid Waste. Gasif. Low Grade Feed. 2018. [CrossRef]

30. Prins, M.J.; Ptasinski, K.J.; Janssen, F.J.J.G. Thermodynamics of gas-char reactions: First and second law analysis. Chem. Eng. Sci. 2003, 58, 1003-1011. [CrossRef]

31. Ivanova, N.; Gugleva, V.; Dobreva, M.; Pehlivanov, I.; Stefanov, S.; Andonova, V. We are IntechOpen, the World's Leading Publisher of Open Access Books Built by Scientists, for Scientists TOP 1\%; IntechOpen: London, UK, 2016.

32. Collard, F.X.; Blin, J. A review on pyrolysis of biomass constituents: Mechanisms and composition of the products obtained from the conversion of cellulose, hemicelluloses and lignin. Renew. Sustain. Energy Rev. 2014, 38, 594-608. [CrossRef]

33. Novak, J.M.; Johnson, M.G. Elemental and Spectroscopic Characterization of Low-Temperature $\left(350{ }^{\circ} \mathrm{C}\right)$ Lignocellulosic-and Manure-based Designer Biochars and Their Use as Soil Amendments; Elsevier Inc.: Amsterdam, The Netherlands, 2018.

34. Sebastiani, A.; Macrì, D.; Gallucci, K.; Materazzi, M. Steam-oxygen gasification of refuse derived fuel in fluidized beds: Modelling and pilot plant testing. Fuel Process. Technol. 2021, 216, 106783. [CrossRef]

35. Zhang, Y.; Chen, P.; Liu, S.; Peng, P.; Min, M.; Cheng, Y.; Anderson, E.; Zhou, N.; Fan, L.; Liu, C.; et al. Effects of feedstock characteristics on microwave-assisted pyrolysis-A review. Bioresour. Technol. 2017, 230, 143-151. [CrossRef]

36. Abnisa, F.; Wan Daud, W.M.A. A review on co-pyrolysis of biomass: An optional technique to obtain a high-grade pyrolysis oil. Energy Convers. Manag. 2014, 87, 71-85. [CrossRef]

37. Bhoi, P.R.; Ouedraogo, A.S.; Soloiu, V.; Quirino, R. Recent advances on catalysts for improving hydrocarbon compounds in bio-oil of biomass catalytic pyrolysis. Renew. Sustain. Energy Rev. 2020, 121, 109676. [CrossRef]

38. Wu, Z.; Luo, H. Pyrolysis Characteristics and Kinetic Analysis of Sediment from the Dianchi Lake in China. Int. J. Chem. Eng. 2018, 2018. [CrossRef]

39. Boateng, A.A.; Mullen, C.A.; Osgood-Jacobs, L.; Carlson, P.; Macken, N. Mass Balance, Energy, and Exergy Analysis of Bio-Oil Production by Fast Pyrolysis. J. Energy Resour. Technol. 2012, 134, 042001. [CrossRef]

40. Grigiante, M.; Ischia, M.; Baratieri, M.; Maschio, R.D.; Ragazzi, M. Pyrolysis analysis and solid residue stabilization of polymers, waste tyres, spruce sawdust and sewage sludge. Waste Biomass Valorization 2010, 1, 381-393. [CrossRef]

41. Salimbeni, A. Techno-Economic Assessment of Lignocellulosic Biomass Energy Conversion by Slow Oxidative Pyrolysis. Master's Thesis, University of Florence, Florence, Italy, 2016.

42. Zhang, Y.; Cui, Y.; Chen, P.; Liu, S.; Zhou, N.; Ding, K.; Fan, L.; Peng, P.; Min, M.; Cheng, Y.; et al. Gasification Technologies and Their Energy Potentials; Elsevier B.V.: Amsterdam, The Netherlands, 2019.

43. Dooley, S.; Won, S.H.; Dryer, F.L. Surrogate Fuels and Combustion Characteristics of Liquid Transportation Fuels; Elsevier B.V.: Amsterdam, The Netherlands, 2019.

44. Westbrook, C.K. Chemical kinetics of hydrocarbon ignition in practical combustion systems. Proc. Combust. Inst. 2000, 28, 1563-1577. [CrossRef]

45. Caretto, L. Introduction to Combustion Today's Class; Spring: Long Beach, CA, USA, 2010; pp. 1-22.

46. Kim, D.; Yoshikawa, K.; Lee, K.; Park, K.Y. Investigation of the combustion characteristics of municipal solid wastes and their hydrothermally treated products via thermogravimetric analysis. J. Mater. Cycles Waste Manag. 2015, 17, 258-265. [CrossRef]

47. Ribeiro, J.M.C.; Godina, R.; Matias, J.C.D.O.; Nunes, L.J.R. Future perspectives of biomass torrefaction: Review of the current state-of-the-art and research development. Sustainability 2018, 10, 2323. [CrossRef]

48. Bergman, P.C.A.; Boersma, A.R.; Zwart, R.W.R.; Kiel, J.H. Torrefaction for Biomass Co-Firing in Existing Coal-Fired Power Stations (BIOCOAL); C-05-013; ECN: Petten, The Netherlands, 2005; pp. 1-72.

49. Bach, Q.V.; Skreiberg, O. Upgrading biomass fuels via wet torrefaction: A review and comparison with dry torrefaction. Renew. Sustain. Energy Rev. 2016, 54, 665-677. [CrossRef]

50. Yue, Y.; Singh, H.; Singh, B.; Mani, S. Torrefaction of sorghum biomass to improve fuel properties. Bioresour. Technol. 2017, 232, 372-379. [CrossRef]

51. Tumuluru, J.S.; Sokhansanj, S.; Wright, C.T.; Kremer, T. GC Analysis of Volatiles and Other Products from Biomass Torrefaction Process; IntechOpen: London, UK, 2012. [CrossRef]

52. Basu, P. Chp. 04: Torrefaction; Biomass Gasification, Pyrolysis and Torrefaction: Halifax, NS, Canada, 2013; pp. 93-154; ISBN 9780128129920. [CrossRef]

53. White, R.H.; Dietenberger, M.A. Wood Products: Thermal Degradation and Fire. Encycl. Mater. Sci. Technol. 2001, 9712-9716. [CrossRef]

54. Acharya, B.; Pradhan, R.R.; Dutta, A. Qualitative and kinetic analysis of torrefaction of lignocellulosic biomass using DSC-TGAFTIR. AIMS Energy 2015, 3, 760-773. [CrossRef]

55. Karki, S.; Poudel, J.; Oh, S.C. Thermal pre-treatment of sewage sludge in a lab-scale fluidized bed for enhancing its solid fuel properties. Appl. Sci. 2018, 8, 183. [CrossRef]

56. Minowa, T.; Kondo, T.; Sudirjo, S.T. Thermochemical liquefaction of Indonesian biomass residues. Biomass Bioenergy 1998, 14, 517-524. [CrossRef]

57. Akhtar, J.; Amin, N.A.S. A review on process conditions for optimum bio-oil yield in hydrothermal liquefaction of biomass. Renew. Sustain. Energy Rev. 2011, 15, 1615-1624. [CrossRef] 
58. Zhou, Y.; Hu, C. Catalytic thermochemical conversion of algae and upgrading of algal oil for the production of high-grade liquid fuel: A review. Catalysts 2020, 10, 145. [CrossRef]

59. Lv, S.H. High-performance superplasticizer based on chitosan. Biopolym. Biotech. Admix. Eco Effic. Constr. Mater. 2016, 131-150. [CrossRef]

60. Gartner, E.M.; MacPhee, D.E. A physico-chemical basis for novel cementitious binders. Cem. Concr. Res. 2011, 41, 736-749. [CrossRef]

61. Weiner, B.; Baskyr, I.; Poerschmann, J.; Kopinke, F.D. Potential of the hydrothermal carbonization process for the degradation of organic pollutants. Chemosphere 2013, 92, 674-680. [CrossRef]

62. Yoganandham, S.T.; Sathyamoorthy, G.; Renuka, R.R. Emerging Extraction Techniques: Hydrothermal Processing; Elsevier Inc.: Amsterdam, The Netherlands, 2020.

63. Ischia, G.; Fiori, L. Hydrothermal Carbonization of Organic Waste and Biomass: A Review on Process, Reactor, and Plant Modeling. Waste Biomass Valorization 2021, 12, 2797-2824. [CrossRef]

64. Chiong, M.C.; Chong, C.T.; Ng, J.H.; Lam, S.S.; Tran, M.V.; Chong, W.W.F.; Mohd Jaafar, M.N.; Valera-Medina, A. Liquid biofuels production and emissions performance in gas turbines: A review. Energy Convers. Manag. 2018, 173, 640-658. [CrossRef]

65. Bonilla, S.H.; Silva, H.R.O.; da Silva, M.T.; Gonçalves, R.F.; Sacomano, J.B. Industry 4.0 and sustainability implications: A scenario-based analysis of the impacts and challenges. Sustainability 2018, 10, 3740. [CrossRef]

66. Gassner, M.; Maréchal, F. Thermo-economic optimisation of the polygeneration of synthetic natural gas (SNG), power and heat from lignocellulosic biomass by gasification and methanation. Energy Environ. Sci. 2012, 5, 5768-5789. [CrossRef]

67. Marriott, P.J.; Chin, S.T.; Nolvachai, Y. Techniques and application in comprehensive multidimensional gas chromatographymass spectrometry. J. Chromatogr. A 2021, 1636, 461788. [CrossRef]

68. Shellie, R.A. Gas Chromatography. Encycl. Forensic Sci. Second Ed. 2013, 1, 579-585. [CrossRef]

69. Asteggiano, A.; Occhipinti, A.; Capuzzo, A.; Mecarelli, E.; Aigotti, R.; Medana, C. Quali-Quantitative Characterization of Volatile and Non-Volatile Compounds in Protium heptaphyllum (Aubl.) Marchand Resin by GC-MS Validated Method, GC-FID and HPLC-HRMS2. Molecules 2021, 26, 1447. [CrossRef]

70. Modern Practice of Gas Chromatography; International Journal of Agriculture Innovation and Research: Wuxi, China, 2017; Volume 42, ISBN 9786468600.

71. Ma, X.M.; Lu, R.; Miyakoshi, T. Application of pyrolysis gas chromatography/mass spectrometry in lacquer research: A review. Polymers 2014, 6, 132-144. [CrossRef]

72. Grams, J. Chromatographic analysis of bio-oil formed in fast pyrolysis of lignocellulosic biomass. Rev. Anal. Chem. 2020, 39, 65-77. [CrossRef]

73. Selection, T.; Tech, A.; Instrument, A. Chapter 5. Analytical techniques used with pyrolysis. Tech. Instrum. Anal. Chem. 1998, 20, 97-199. [CrossRef]

74. González Martínez, M.; Dupont, C.; Thiéry, S.; Meyer, X.M.; Gourdon, C. Impact of biomass diversity on torrefaction: Study of solid conversion and volatile species formation through an innovative TGA-GC/MS apparatus. Biomass Bioenergy 2018, 119, 43-53. [CrossRef]

75. Netzsch TGA-GC-MS Coupling Thermogravimetry and Evolved Gas Analysis; Netzsch: Selb, Germany, $2012 ;$ p. 20.

76. Boyron, O.; Marre, T.; Delauzun, A.; Cozic, R.; Boisson, C. An Advanced Technique for Linear Low-Density Polyethylene Composition Determination: TGA-IST16-GC-MS Coupling. Macromol. Chem. Phys. 2019, 220, 1-9. [CrossRef]

77. Amaral, M.S.S.; Nolvachai, Y.; Marriott, P.J. Comprehensive Two-Dimensional Gas Chromatography Advances in Technology and Applications: Biennial Update. Anal. Chem. 2020, 92, 85-104. [CrossRef] [PubMed]

78. Kandiyoti, R.; Herod, A.A.; Bartle, K.D. Analytical Techniques for Low Mass Materials: Method Development. Solid Fuels Heavy Hydrocarb. Liq. 2006, 217-260. [CrossRef]

79. El Hayany, B.; El Fels, L.; Dignac, M.F.; Quenea, K.; Rumpel, C.; Hafidi, M. Pyrolysis-GCMS as a Tool for Maturity Evaluation of Compost from Sewage Sludge and Green Waste. Waste Biomass Valorization 2021, 12, 2639-2652. [CrossRef]

80. Gupta, J.; Papadikis, K.; Kozhevnikov, I.V.; Konysheva, E.Y. Exploring the potential of red mud and beechwood co-processing for the upgrading of fast pyrolysis vapours. J. Anal. Appl. Pyrolysis 2017, 128, 35-43. [CrossRef]

81. Schilling, M.R.; Learner, T. Evolved Gas Analysis As a Tool for Characterizing Plastics. In Proceedings of the ICOM-CC 16th Trienn. Conference, Lisbon, Spain, 19-23 September 2011.

82. Akihiko, H.; Koichi, I.; Ichi, W.; Chuichi, W. Utility of a System Consisting of EGA.PY-3030D and GCMS-QP2010 Ultra, SHIMADZU, C146-E174.

83. Pua, F.L.; Zakaria, S.; Chia, C.H.; Fan, S.P.; Rosenau, T.; Potthast, A.; Liebner, F. Solvolytic liquefaction of oil palm empty fruit bunch (EFB) fibres: Analysis of product fractions using FTIR and pyrolysis-GCMS. Sains Malays. 2013, 42, $793-799$.

84. Wei, L.; Liang, S.; Guho, N.M.; Hanson, A.J.; Smith, M.W.; Garcia-Perez, M.; McDonald, A.G. Production and characterization of bio-oil and biochar from the pyrolysis of residual bacterial biomass from a polyhydroxyalkanoate production process. J. Anal. Appl. Pyrolysis 2015, 115, 268-278. [CrossRef]

85. Branca, C.; Giudicianni, P.; Di Blasi, C. GC/MS characterization of liquids generated from low-temperature pyrolysis of wood. Ind. Eng. Chem. Res. 2003, 42, 3190-3202. [CrossRef]

86. Ukaew, S.; Schoenborn, J.; Klemetsrud, B.; Shonnard, D.R. Effects of torrefaction temperature and acid pretreatment on the yield and quality of fast pyrolysis bio-oil from rice straw. J. Anal. Appl. Pyrolysis 2018, 129, 112-122. [CrossRef] 
87. Li, W.; Wu, S.; Wu, Y.; Huang, S.; Gao, J. Gasification characteristics of biomass at a high-temperature steam atmosphere. Fuel Process. Technol. 2019, 194, 106090. [CrossRef]

88. Xu, D.; Xiong, Y.; Ye, J.; Su, Y.; Dong, Q.; Zhang, S. Performances of syngas production and deposited coke regulation during co-gasification of biomass and plastic wastes over $\mathrm{Ni} / \gamma-\mathrm{Al}_{2} \mathrm{O}_{3}$ catalyst: Role of biomass to plastic ratio in feedstock. Chem. Eng. J. 2020, 392, 123728. [CrossRef]

89. Cai, W.; Liu, Q.; Shen, D.; Wang, J. Py-GC/MS analysis on product distribution of two-staged biomass pyrolysis. J. Anal. Appl. Pyrolysis 2019, 138, 62-69. [CrossRef]

90. Rathsack, P.; Wollmerstaedt, H.; Kuchling, T.; Kureti, S. Analysis of hydrogenation products of biocrude obtained from hydrothermally liquefied algal biomass by comprehensive gas chromatography mass spectrometry (GC $\times$ GC-MS). Fuel 2019, 248, 178-188. [CrossRef]

91. Sun, T.; Li, Z.; Zhang, Z.; Wang, Z.; Yang, S.; Yang, Y.; Wang, X.; Liu, S.; Zhang, Q.; Lei, T. Fast corn stalk pyrolysis and the influence of catalysts on product distribution. Bioresour. Technol. 2020, 301, 122739. [CrossRef]

92. Zhang, L.; Li, K.; Zhu, X. Study on two-step pyrolysis of soybean stalk by TG-FTIR and Py-GC/MS. J. Anal. Appl. Pyrolysis 2017, 127, 91-98. [CrossRef]

93. Xu, Q.; Pang, S.; Levi, T. Reaction kinetics and producer gas compositions of steam gasification of coal and biomass blend chars, part 1: Experimental investigation. Chem. Eng. Sci. 2011, 66, 2141-2148. [CrossRef]

94. Zhu, L.; Zhang, Y.; Lei, H.; Zhang, X.; Wang, L.; Bu, Q.; Wei, Y. Production of hydrocarbons from biomass-derived biochar assisted microwave catalytic pyrolysis. Sustain. Energy Fuels 2018, 2, 1781-1790. [CrossRef]

95. Pantami, H.A.; Bustamam, M.S.A.; Lee, S.Y.; Ismail, I.S.; Faudzi, S.M.M.; Nakakuni, M.; Shaari, K. Comprehensive GCMS and LC-MS/MS metabolite profiling of chlorella vulgaris. Mar. Drugs 2020, 18, 367. [CrossRef] [PubMed]

96. Sharma, D.K.; Dhawan, H.; Morgan, T.; Crocker, M. Py-GCMS studies of Indian coals and their solvent extracted products. Fuel 2019, 256, 115981. [CrossRef]

97. Hidayat, S.; Abu Bakar, M.S.; Yang, Y.; Phusunti, N.; Bridgwater, A.V. Characterisation and Py-GC/MS analysis of Imperata Cylindrica as potential biomass for bio-oil production in Brunei Darussalam. J. Anal. Appl. Pyrolysis 2018, 134, 510-519. [CrossRef]

98. Zhang, B.; Zhong, Z.P.; Wang, X.B.; Ding, K.; Song, Z.W. Catalytic upgrading of fast pyrolysis biomass vapors over fresh, spent and regenerated ZSM-5 zeolites. Fuel Process. Technol. 2015, 138, 430-434. [CrossRef]

99. Zhang, S.; Zhu, S.; Zhang, H.; Chen, T.; Xiong, Y. Catalytic fast pyrolysis of rice husk: Effect of coupling leaching with torrefaction pretreatment. J. Anal. Appl. Pyrolysis 2018, 133, 91-96. [CrossRef]

100. Mattonai, M.; Watanabe, A.; Shiono, A.; Ribechini, E. Degradation of wood by UV light: A study by EGA-MS and Py-GC/MS with on line irradiation system. J. Anal. Appl. Pyrolysis 2019, 139, 224-232. [CrossRef]

101. Sabatini, F.; Nacci, T.; Degano, I.; Colombini, M.P. Investigating the composition and degradation of wool through EGA/MS and Py-GC/MS. J. Anal. Appl. Pyrolysis 2018, 135, 111-121. [CrossRef]

102. Merckel, R.D.; Heydenrych, M.D.; Sithole, B.B. Pyrolysis oil composition and catalytic activity estimated by cumulative mass analysis using Py-GC/MS EGA-MS. Energy 2021, 219, 119428. [CrossRef]

103. Peng, Y.-Y.; Dussan, D.D.; Narain, R. Thermal, mechanical, and electrical properties. Polym. Sci. Nanotechnol. 2020, $179-201$. [CrossRef]

104. Tomoda, B.T.; Yassue-Cordeiro, P.H.; Ernesto, J.V.; Lopes, P.S.; Péres, L.O.; da Silva, C.F.; de Moraes, M.A. Characterization of biopolymer membranes and films: Physicochemical, mechanical, barrier, and biological properties. Biopolym. Membr. Film. 2020, 67-95. [CrossRef]

105. Ebnesajjad, S. Surface and Material Characterization Techniques; William Andrew Publishing: Norwich, NY, USA, 2014; ISBN 9780323264358.

106. Schubnell, M. Thermogravimetry and gas analysis, Part 1: Basic principles and overview. Mettler Toledo User Com 2017, 45, 1-9.

107. Heetderks, B.T.; Wang, X. Thermogravimetric Analysis-Fourier Transfer Infrared Spectroscopy (TGA-FTIR) Services Thermogravimetric Analysis-Fourier Transfer Infrared Spectroscopy ( TGA-FTIR) Services. EAG Appl. Note 2019, M-039719.

108. Parshetti, G.K.; Quek, A.; Betha, R.; Balasubramanian, R. TGA-FTIR investigation of co-combustion characteristics of blends of hydrothermally carbonized oil palm biomass (EFB) and coal. Fuel Process. Technol. 2014, 118, 228-234. [CrossRef]

109. Toledo, M. Thermogravimetry and Gas Analysis, Part 2: TGA-MS; METTLER TOLEDO Thermal Analysis UserCom45: Selangor, Malaysia, 2017; pp. 1-5.

110. Thermal Gravimetric Analysis. Available online: http:/ / mcl-inc.com/instrumentation/thermal/ (accessed on 29 April 2020).

111. Wang, X.; Deng, S.; Tan, H.; Adeosun, A.; Vujanović, M.; Yang, F.; Duić, N. Synergetic effect of sewage sludge and biomass co-pyrolysis: A combined study in thermogravimetric analyzer and a fixed bed reactor. Energy Convers. Manag. 2016, 118, 399-405. [CrossRef]

112. Guo, F.; Li, X.; Wang, Y.; Liu, Y.; Li, T.; Guo, C. Characterization of Zhundong lignite and biomass co-pyrolysis in a thermogravimetric analyzer and a fixed bed reactor. Energy 2017, 141, 2154-2163. [CrossRef]

113. Jin, Q.; Wang, X.; Li, S.; Mikulčić, H.; Bešenić, T.; Deng, S.; Vujanović, M.; Tan, H.; Kumfer, B.M. Synergistic effects during co-pyrolysis of biomass and plastic: Gas, tar, soot, char products and thermogravimetric study. J. Energy Inst. 2019, 92, 108-117. [CrossRef] 
114. Moya, R.; Rodríguez-Zúñiga, A.; Puente-Urbina, A.; Gaitán-Álvarez, J. Study of light, middle and severe torrefaction and effects of extractives and chemical compositions on torrefaction process by thermogravimetric analysis in five fast-growing plantations of Costa Rica. Energy 2018, 149, 1-10. [CrossRef]

115. Botelho, T.; Costa, M.; Wilk, M.; Magdziarz, A. Evaluation of the combustion characteristics of raw and torrefied grape pomace in a thermogravimetric analyzer and in a drop tube furnace. Fuel 2018, 212, 95-100. [CrossRef]

116. Kantová, N.; Holubčík, M.; Jandačka, J.; Čaja, A. Comparison of Particulate Matters Properties from Combustion of Wood Biomass and Brown Coal. Procedia Eng. 2017, 192, 416-420. [CrossRef]

117. Balasundram, V.; Alias, N.; Ibrahim, N.; Kasmani, R.M.; Isha, R.; Abd. Hamid, M.K.; Hasbullah, H. Thermal Characterization of Malaysian Biomass via Thermogravimetric Analysis. J. Energy Saf. Technol. 2018, 1, 31-38. [CrossRef]

118. Vuppaladadiyam, A.K.; Antunes, E.; Sanchez, P.B.; Duan, H.; Zhao, M. Influence of microalgae on synergism during co-pyrolysis with organic waste biomass: A thermogravimetric and kinetic analysis. Renew. Energy 2021, 167, 42-55. [CrossRef]

119. Granados, D.A.; Ruiz, R.A.; Vega, L.Y.; Chejne, F. Study of reactivity reduction in sugarcane bagasse as consequence of a torrefaction process. Energy 2017, 139, 818-827. [CrossRef]

120. Patrick, D.O.; Yusup, S.; Osman, N.B.; Zabiri, H.; Shahbaz, M. Performance of water-leached coal bottom ash as catalyst in Thermogravimetric Analyser (TGA) biomass gasification. Chem. Eng. Trans. 2017, 61, 1681-1686. [CrossRef]

121. Gajera, Z.R.; Verma, K.; Tekade, S.P.; Sawarkar, A.N. Kinetics of co-gasification of rice husk biomass and high sulphur petroleum coke with oxygen as gasifying medium via TGA. Bioresour. Technol. Rep. 2020, 11, 100479. [CrossRef]

122. Yang, X.; Liu, X.; Li, R.; Liu, C.; Qing, T.; Yue, X.; Zhang, S. Co-gasification of thermally pretreated wheat straw with Shengli lignite for hydrogen production. Renew. Energy 2018, 117, 501-508. [CrossRef]

123. Thengane, S.K.; Gupta, A.; Mahajani, S.M. Co-gasification of high ash biomass and high ash coal in downdraft gasifier. Bioresour. Technol. 2019, 273, 159-168. [CrossRef] [PubMed]

124. Puig-Gamero, M.; Lara-Díaz, J.; Valverde, J.L.; Sanchez-Silva, L.; Sánchez, P. Dolomite effect on steam co-gasification of olive pomace, coal and petcoke: TGA-MS analysis, reactivity and synergistic effect. Fuel 2018, 234, 142-150. [CrossRef]

125. Pahla, G.; Ntuli, F.; Muzenda, E. Torrefaction of landfill food waste for possible application in biomass co-firing. Waste Manag. 2018, 71, 512-520. [CrossRef]

126. Barzegar, R.; Yozgatligil, A.; Olgun, H.; Atimtay, A.T. TGA and kinetic study of different torrefaction conditions of wood biomass under air and oxy-fuel combustion atmospheres. J. Energy Inst. 2020, 93, 889-898. [CrossRef]

127. Ma, Z.; Wang, J.; Yang, Y.; Zhang, Y.; Zhao, C.; Yu, Y.; Wang, S. Comparison of the Thermal Degradation Behaviors and Kinetics of Palm Oil Waste under Nitrogen and Air Atmosphere in TGA-FTIR with a Complementary Use of Model-Free and Model-Fitting Approaches, Elsevier: Amsterdam, The Netherlands, 2018.

128. Kanca, A. Investigation on pyrolysis and combustion characteristics of low quality lignite, cotton waste, and their blends by TGA-FTIR. Fuel 2020, 263, 116517. [CrossRef]

129. Halder, P.; Kundu, S.; Patel, S.; Parthasarathy, R.; Pramanik, B.; Paz-Ferreiro, J.; Shah, K. TGA-FTIR study on the slow pyrolysis of lignin and cellulose-rich fractions derived from imidazolium-based ionic liquid pre-treatment of sugarcane straw. Energy Convers. Manag. 2019, 200, 112067. [CrossRef]

130. Wang, S.; Uzoejinwa, B.B.; Abomohra, A.E.F.; Wang, Q.; He, Z.; Feng, Y.; Zhang, B.; Hui, C.W. Characterization and pyrolysis behavior of the green microalga Micractinium conductrix grown in lab-scale tubular photobioreactor using Py-GC/MS and TGA/MS. J. Anal. Appl. Pyrolysis 2018, 135, 340-349. [CrossRef]

131. Manić, N.G.; Janković, B.Ž.; Stojiljković, D.D.; Jovanović, V.V.; Radojević, M.B. Tga-Dsc-Ms Analysis of Pyrolysis Process. Therm. Sci. 2019, 23, 1457-1472. [CrossRef]

132. Sindhu, R.; Binod, P.; Pandey, A. Microbial Poly-3-Hydroxybutyrate and Related Copolymers; Elsevier B.V.: Amsterdam, The Netherlands, 2015.

133. Stark, W.; Bohmeyer, W. Non-Destructive Evaluation (NDE) of Composites: Using Ultrasound to Monitor the Curing of Composites; Woodhead Publishing: Sawston, UK, 2013.

134. Wang, S.; Yu, S.; Siedler, M.; Ihnat, P.M.; Filoti, D.I.; Lu, M.; Zuo, L. A power compensated differential scanning calorimeter for protein stability characterization. Sens. Actuators B Chem. 2018, 256, 946-952. [CrossRef]

135. Pecchi, M.; Patuzzi, F.; Basso, D.; Baratieri, M. Enthalpy change during hydrothermal carbonization of biomass: A critical review. J. Therm. Anal. Calorim. 2020, 141, 1251-1262. [CrossRef]

136. Pecchi, M.; Patuzzi, F.; Benedetti, V.; Di Maggio, R.; Baratieri, M. Thermodynamics of hydrothermal carbonization: Assessment of the heat release profile and process enthalpy change. Fuel Process. Technol. 2020, 197, 106206. [CrossRef]

137. Pecchi, M.; Patuzzi, F.; Benedetti, V.; Di Maggio, R.; Baratieri, M. Kinetic analysis of hydrothermal carbonization using highpressure differential scanning calorimetry applied to biomass. Appl. Energy 2020, 265, 114810. [CrossRef]

138. Pecchi, M.; Patuzzi, F.; Benedetti, V.; Basso, D.; Baratieri, M. Evaluation of the overall reaction enthalpy change of hydrothermal carbonization process by means of differential scanning calorimetry at high pressure. Eur. Biomass Conf. Exhib. Proc. 2019, 1160-1163. [CrossRef]

139. Funke, A.; Ziegler, F. Propagation of uncertainties and systematic errors in the measurements of long-lasting heat flows using differential scanning calorimetry. J. Therm. Anal. Calorim. 2012, 108, 1317-1324. [CrossRef]

140. Ibbett, R.; Gaddipati, S.; Tucker, G. In-situ studies of hydrothermal reactions of lignocellulosic biomass using high-pressure differential scanning calorimetry. Biomass Bioenergy 2019, 121, 48-55. [CrossRef] 
141. Benefits Thermogravimetric Gas Chromatography Mass Spectrometry. Available online: https://www.chromatographyonline. com/view/benefits-thermogravimetric-gas-chromatography-mass-spectrometry (accessed on 1 May 2020).

142. Lin, X.; Sui, S.; Tan, S.; Pittman, C.U.; Sun, J.; Zhang, Z. Fast pyrolysis of four lignins from different isolation processes using Py-GC/MS. Energies 2015, 8, 5107-5121. [CrossRef] 